\title{
The Chipmakers
}

U.S. Strengths and Priorities for the High-End

Semiconductor Workforce

CSET Issue Brief

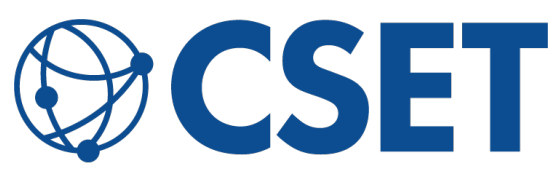

AUTHORS

Will Hunt

Remco Zwetsloot

CENTER for SECURITY and

EMERGING TECHNOLOGY 


\section{Table of Contents}

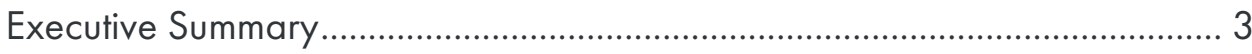

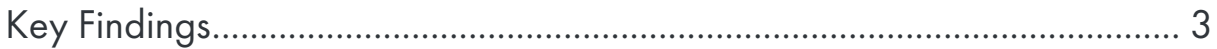

Workforce Policy Recommendations........................................................... 5

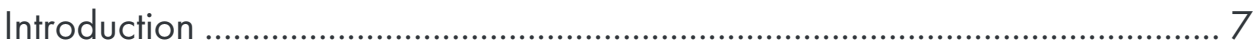

Why Talent Matters and the American Talent Advantage ............................. 10

Mapping the U.S. Semiconductor Workforce................................................. 12

Identifying and Analyzing the Semiconductor Workforce........................ 12

A Large and International Workforce......................................................... 14

The University Talent Pipeline ......................................................................... 16

Talent Across the Semiconductor Supply Chain ......................................... 21

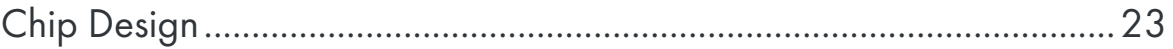

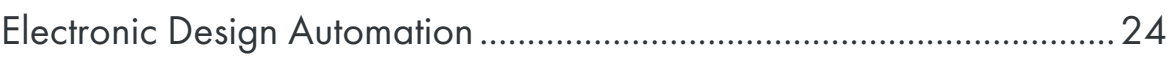

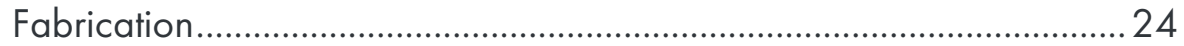

Semiconductor Manufacturing Equipment (SME) Suppliers .................. 25

Points of Origin Across the Supply Chain ............................................... 25

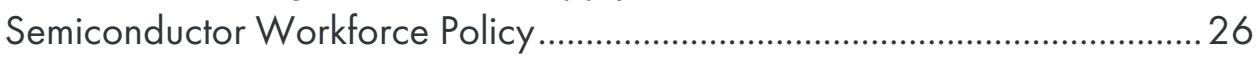

Protect: Preventing International Technology Transfer ............................... 27

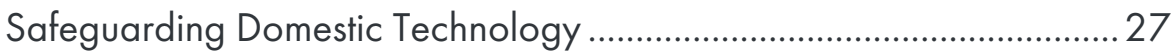

Collaborating with Allies and Partners .........................................................29

Promote: Strengthening the Semiconductor Workforce ..............................30

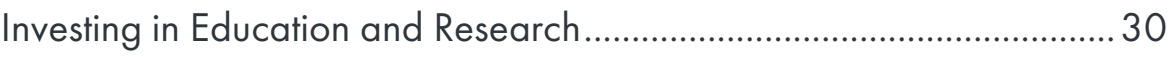

Retaining and Expanding Immigration Pipelines ..................................... 32

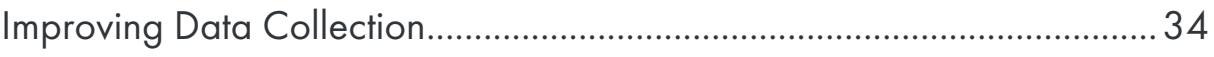

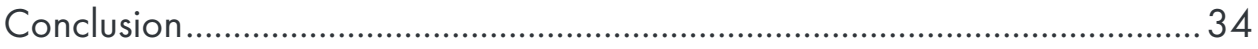

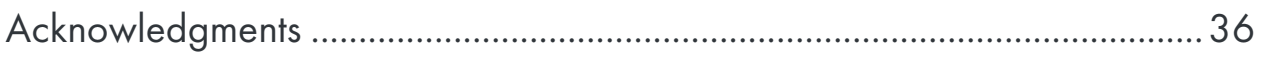

Appendix A: Definitional and Measurement Issues ......................................... 37

Appendix B: American Community Survey Data ............................................. 38

Appendix C: Green Card Data ...................................................................... 41

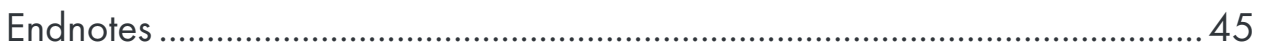




\section{Executive Summary}

Technical leadership in the semiconductor industry has been a cornerstone of U.S. military and economic power for decades. Semiconductor innovation is a key driver of progress in critical technologies such as artificial intelligence, while the Internet of Things has introduced ever-more sophisticated computer chips into everything from toasters to highways. But continued competitiveness is not guaranteed: top American firms face foreign competitors, often backed by concerted government support, in a number of high-value parts of the semiconductor supply chain.

To remain competitive and ensure access to secure and leading-edge computer chips, the United States will need to leverage one of its greatest strengths: its capacity to attract, develop, and retain the deepest bench of science and engineering talent in the world-both at home and from abroad. This report explores the composition of the talented workforce that undergirds continued U.S. leadership in the semiconductor industry, and assesses workforce policy options for protecting and promoting technological competitiveness going forward.

\section{Key Findings}

Based on original analysis of six different datasets and a range of secondary sources, this paper finds that:

- Semiconductors and semiconductor talent are of critical importance to the United States.

- U.S. semiconductor firms generate tremendous economic value; in 2018 , their sales totaled more than $\$ 200$ billion, capturing 45 percent of the global market.

- The United States benefits from a number of semiconductor talent clusters, including California's Silicon Valley, New York's Tech Valley, and Oregon's Silicon Forest, which draw top technical talent and firms from around the world.

- In a 2017 survey, 91 percent of employers believed the industry would face a "critical" or "severe" shortage by 2020. Wages in the industry have grown 4.4 percent per year on average since 2001 -significantly faster than wage growth in other engineering occupations and in the U.S. economy as a whole. 
- Demand for high-skilled technical semiconductor talent is likely to remain high despite trends toward automation.

- The best estimates suggest the U.S. semiconductor industry employs about 240,000 workers, spanning a diverse set of skills and positions from manufacturing to research and development.

- The Bureau of Labor Statistics predicts a 10.6 percent overall decline in absolute employment numbers in the semiconductor industry between 2018 and 2028. Predicted job losses are concentrated in areas susceptible to automation-primarily in the lower-skilled parts of the workforce.

- Foreign talent contributes significantly to U.S. semiconductor innovation.

- Approximately 40 percent of high-skilled semiconductor workers in the United States were born abroad. India is the most common place of origin among foreign-born workers, followed by China.

- In 2011,87 percent of semiconductor patents awarded to top U.S. universities had at least one foreign-born inventor. Between 2000 and 2010, the United States enjoyed a net influx of about 100,000 electrical engineering patent holders, while India and China saw large net oufflows.

- While international talent is important to the health of the semiconductor industry, it has also played a role in building up competitors to U.S. companies.

- Top semiconductor companies abroad, such as the Taiwan Semiconductor Manufacturing Company (TSMC), were founded and staffed by returnees who received their training in the United States.

- China seeks to attract semiconductor talent from abroad. So far, its success has been limited, and there is currently no evidence of significant talent oufflow from the United States to China. But this does not mean there is no risk; even a small number of skilled returnees could help to accelerate China's progress toward the cutting edge.

- U.S. universities are the main pathway by which foreign-born semiconductor talent comes to the United States.

- International students comprise around two-thirds of graduate students in electrical engineering and computer science, the top educational fields feeding into the U.S. semiconductor industry among green card applicants. 
- The number of American students enrolled in semiconductorrelated graduate programs (around 90,000) has not increased since 1990. In that same period, the number of international students nearly tripled from 50,000 to 140,000 .

- More than 80 percent of international Ph.D. graduates from semiconductor-related fields at U.S. universities stay in the country after completing their degrees. Stay rates are highest among Indian and Chinese doctoral recipients.

- The semiconductor supply chain is highly specialized, and skill demands and workforce composition vary between different parts of the supply chain.

- The overwhelming majority of green card applicants sponsored by design firms earned their highest degree in either electrical and computer engineering or computer science.

- By contrast, green card applicants sponsored by manufacturing equipment suppliers and foundries have a much wider range of academic backgrounds. More than half held degrees in disciplines such as chemical and mechanical engineering, materials science, and physics.

- Across all parts of the supply chain, India was by far the most common place of origin among green card applicants, followed by China.

\section{Workforce Policy Recommendations}

Policymakers can protect and promote the competitiveness of the U.S. semiconductor workforce by strengthening the country's talent pipelines:

- To prevent technology transfer, the U.S. government can bolster domestic protections and engage with allies and partners.

- Tools such as visa screening, deemed export licensing, and intellectual property and espionage enforcement can-if used judiciously-help protect semiconductor companies from employees with malicious intent. However, counter-transfer policies not focused on talent, such as foreign investment screening and enhanced cyber protections, are likely to do more to protect semiconductor technology while also posing less risk to U.S. competitiveness.

- Collaboration with allies and partners is crucial for controlling the flow of cutting-edge semiconductor talent and technology. South Korea, Taiwan, Japan, the Netherlands, and the United 
Kingdom are home to the most important semiconductor companies outside of the United States.

- To strengthen the U.S. semiconductor workforce, policymakers should invest in domestic education and research.

- Anticipating future technical challenges to semiconductor innovation, research and education investments should target a broad range of physical science and engineering fields and technologies. Funding can be allocated both to universities and to government-industry-academic partnerships.

- These investments should also be used to encourage more domestic students to do semiconductor-related graduate programs and to incentivize on-the-job training models through internship and apprenticeship programs.

- To continue attracting and retaining international talent, policymakers should retain and strengthen the immigration pathways available to high-skill semiconductor workers.

- At minimum, policymakers should sustain immigration programs that are crucial to the semiconductor industry, such as the Optional Practical Training (OPT) program. These programs have faced significant threats in recent years.

- Options for targeted or broad immigration reforms that would aid the semiconductor industry include eliminating countrybased caps on green cards and increasing the number of available employment-based visas.

- To enable data-driven and targeted workforce policies, federal agencies should improve their semiconductor industry-related data collection.

- The Office of Management and Budget should alter its classification system to distinguish semiconductor firms from other electronic component manufacturers and to include chip design ("fabless") firms within the semiconductor industry.

- The National Science Foundation should expand its surveys of U.S. university graduates to include master's students, who make up a large proportion of future high-skilled semiconductor employees. Currently, the NSF only collects detailed data on Ph.D. graduates. 


\section{Introduction}

In 1959, Bell Labs researchers Mohamed M. Atalla and Dawon Kahng coated a thin wafer of silicon with a thermally oxidized layer of silicon dioxide, and placed a metallic gate electrode on top. In doing so, they created the "metal-oxide-semiconductor field-effect transistor" (MOSFET)the world's first transistor amenable to miniaturization and mass-production. Mohamed Atalla was born in Port Said, Egypt and earned his bachelor's degree from Cairo University before coming to the United States for an M.S. and Ph.D. in mechanical engineering from Purdue University. Dawon Kahng was born in Seoul, South Korea, and earned his bachelor's from Seoul National University before coming to the United States by way of a master's and Ph.D. in physics at The Ohio State University.

The work of Atalla and Kahng got the attention of a researcher at Fairchild Semiconductor, a new integrated circuit manufacturer in San Jose, California. That researcher, Chih-Tang Sah, led a 64-person team in the design and volume production of first-generation integrated circuits based on the MOSFET transistor. In the process, he and Frank Wanlass invented the CMOS fabrication process now used for nearly all integrated circuits. Sah was born in Beijing, China, but came to the United States for college, earning two bachelor's degrees from the University of Illinois Urbana-Champaign and an M.S. and Ph.D. from Stanford.

Researchers from Fairchild went on to found a slew of extraordinarily successful semiconductor manufacturers in the area around San Jose. These firms, which came to be known as the "Fairchildren," built their business models around Atalla and Kahng's silicon-based MOSFET. 'By the 1970s, the region in which they proliferated had earned the name Silicon Valley.

Today, the MOSFET remains the basic building block underlying the vast majority of semiconductor chips, and therefore almost all modern electronics. Of course, Atalla and Kahng built on the contributions of many talented engineers, many of whom were born and raised in the United States. ${ }^{2}$ But immigrants to the United States have played significant roles throughout the history of semiconductor innovation. For example, Chenming $\mathrm{Hu}$, a Taiwanese professor of electrical engineering and computer science at the University of California, Berkeley, was central to the invention and commercialization of the FinFET transistor, currently used in the most advanced Intel, TSMC, and Samsung chips. ${ }^{3}$ Indeed, as this paper will show, talent-both domestic and international-remains just as essential to the U.S. 
semiconductor industry today as it was when Atalla and Kahng made their first MOSFET.

\section{Box 1: Semiconductors and Moore's Law}

"Semiconductor" is a generic term for any material that conducts electricity better than insulators like glass, but worse than conductors like copper. By applying chemical impurities to semiconductor materials, engineers can create tiny electronic gates capable of switching on and off an electrical current. The openings and closings of these gates-called transistorsencode the zeroes and ones that power almost all the world's electronics, from toasters to supercomputers. Because of the crucial role that semiconductor materials, most notably silicon, play in electronics, the word "semiconductor" has become a synonym for "computer chip."

The central challenge of the semiconductor industry-the challenge that has driven its decades of growth into a more than $\$ 400$ billion global industryis to pack exponentially increasing numbers of transistors onto the surface of wafer-thin slices of silicon, by far the most popular semiconductor material. In 2015, leading chip manufacturer TSMC managed to fit 37.5 million transistors into a single square millimeter of silicon (on its $16 \mathrm{~nm}$ chip). ${ }^{4}$ In 2017: 52.5 million (on its 10nm chip). ${ }^{5}$ In 2018 : 96.5 million (on its $5 \mathrm{~nm}$ chip). ${ }^{6}$

As these numbers suggest, in the semiconductor industry, "exponential" is not a buzzword but a business plan, and even a law. Moore's Law, first articulated in 1965 by Intel co-founder Gordon Moore, describes a decades-long trend in which the density of transistors-the transistor count per unit chip area-on the most cutting-edge microchips doubles every two years. ${ }^{7}$ Moore put this observation at the center of Intel's long-term planning, and firms hoping to compete with Intel were forced to do the same. Since 1975, Moore's Law has governed the industry's progress from thousands to billions of transistors per chip, and transformed our lives in the process.

Atalla and Kahng unknowingly helped set into motion Moore's Law: a 40year exponential trend in semiconductor progress whose economic and strategic import can hardly be overstated (see Box 1). In 2018 , U.S. firms had semiconductor sales of more than $\$ 200$ billion globally, capturing 45 percent of the global market that year. ${ }^{8}$ The Internet of Things and artificial intelligence are beginning to deliver the productivity gains of Moore's Law 
into formerly low-tech sectors of the economy, likely generating tens of billions of dollars of revenue growth for the semiconductor industry over just the next few years. ${ }^{9}$ Meanwhile, the U.S. military depends heavily on advanced semiconductor technology, which powers everything from the control systems of F-35's to DoD's Global Information Grid. ${ }^{10}$ Defense officials fear that foreign chip supplies, currently essential to American infrastructure and weapons systems, can be sabotaged by an adversary or blocked by trade disruptions. ${ }^{11}$

At the same time, there are storm clouds on the horizon for U.S.

semiconductor firms. Today, American firms across a number of parts of the semiconductor supply chain face serious competitors based all around the world, including in Japan, South Korea, Taiwan, the Netherlands, and the United Kingdom. ${ }^{12}$ Competition is intense and often hinges on risky research bets made years in advance. The Chinese government is investing heavily in building up its semiconductor industry, though its success has been limited. ${ }^{13}$ At home, U.S. semiconductor companies are threatened by calls to limit or end immigration pathways such as the Optional Practical Training (OPT) and $\mathrm{H}-1 \mathrm{~B}$ programs, which, as discussed below, could cut off a large part of the industry's talent pipeline. ${ }^{14}$

All this comes at a time of significant uncertainty for the industry as a whole: Gordon Moore himself said in 2015, "I see Moore's Law dying here in the next decade or so." 15 In the four years since, only a handful of semiconductor manufacturers have managed to keep up with the projections of Moore's Law, and even they are coming up against physical limits that may force a paradigm shift in semiconductor innovation. ${ }^{16}$ If Moore's Law does falter, latecomers to the industry could catch up or displace American firms as global leaders-a worrying outcome, particularly with respect to U.S. national security. To counter this risk, the United States will need to leverage its enduring strength: the deep bench of highly talented semiconductor researchers and engineers-both domestic and international-studying at U.S. universities and employed by U.S. firms.

This paper is organized as follows. Chapter 2 explains how and why talent is an essential driver of U.S. semiconductor leadership. Chapter 3 defines in a more precise way what we mean by the "semiconductor workforce" and uses census, economic, and immigration data to analyze its composition in terms of nationality and educational background. It also breaks down the semiconductor supply chain into parts and analyzes variation in educational backgrounds across these parts. Chapter 4 discusses policy priorities and 
tools that policymakers can use to strengthen the U.S. semiconductor workforce while also guarding against technology transfer.

\section{Why Talent Matters and the American Talent Advantage}

As the case of Atalla and Kahng illustrates, success in the semiconductor industry currently depends on access to technical talent. ${ }^{17}$ And, while workforce shortages are difficult to measure, indicators such as employer sentiment and salary statistics suggest that this talent is in short supply. ${ }^{18}$ Wages in the semiconductor industry have been growing an average of 4.4 percent per year since 2001 -significantly faster than wage growth in other manufacturing jobs and in the U.S. economy as a whole. ${ }^{19}$ In a 2017 Deloitte-SEMI survey, 88 percent of semiconductor executives believed that new digital business technologies-including automation, analytics, and machine learning-would require new skills and talent. Another 77 percent believed the industry was facing a critical talent shortage, and 14 percent expected to face a severe talent shortage by $2020 .{ }^{20}$

High-skilled semiconductor talent tends to cluster, in part because the knowhow necessary for developing novel semiconductor technologies is often tacit-acquired only through hands-on learning and active mentorship from experienced scientists and engineers. ${ }^{21}$ Detailed blueprints, licenses,

sophisticated manufacturing equipment, and academic training are important, but they can't substitute for technical know-how learned on the job. ${ }^{22}$ Because tacit semiconductor knowledge diffuses slowly, from person to person, those with a great deal of this knowledge tend to gather in certain firms, cities, and countries, allowing them to more easily share and build upon each other's knowledge. ${ }^{23}$ This clustering, along with the high and increasing capital requirements for semiconductor manufacturing, has generated a winner-takeall dynamic, and considerable market concentration. ${ }^{24}$

Fortunately, because American firms founded the semiconductor industry, the United States is home to a disproportionate number of industry talent clusters. As mentioned above, Silicon Valley gets its name from silicon-intensive semiconductor firms like Fairchild Semiconductor, which initiated the area's decades-long productivity explosion. A number of other major-albeit lesserknown-semiconductor clusters such as Oregon's "Silicon Forest" and New York's "Tech Valley" also contribute to the sector's tremendous innovation. Almost all clusters in the United States are located near major research universities, precisely to ensure access to talent. ${ }^{25}$ 
The semiconductor industry's winner-take-all dynamic often leads places with pre-existing talent pools to attract more firms, which in turn train and attract more talent. Such virtuous cycles contribute to the difficulty of breaking into the semiconductor market. When nations do manage to break in, as South Korea and Taiwan did several decades ago, they do so partly by figuring out how to attract large numbers of scientists and engineers from abroad-most often the United States (see Box 2).

In short, to maintain its leadership in the global semiconductor supply chain, the United States must also maintain its role as the world's primary hub for semiconductor talent. To do so, policymakers need a more detailed understanding of the U.S. semiconductor workforce itself, and the pipelines into that workforce. The next chapter breaks down what we know, and what we don't, about U.S. semiconductor workers and where they come from.

\section{Box 2. Taiwan and the Importance of Returnee Talent}

Because semiconductor design and manufacturing know-how is tacit, residing largely in the minds of high-skilled engineers rather than blueprints or other technical documents, countries seeking to develop a semiconductor hub of their own have often focused on recruiting "returnee talent" trained at top semiconductor firms in other countries, especially the United States.

Taiwan offers perhaps the most successful example of this strategy. Today, it is home to multiple hubs for semiconductor manufacturing. In the 1970s, however, Taiwan had only a handful of indigenous semiconductor firms, limited investment, and was plagued by the "brain drain" of top Taiwanese STEM talent to other places. Silicon Valley in particular enjoyed a significant inflow of Taiwanese STEM talent from the 1960s through the 1980s: in the early 1980s, for example, two-thirds of Chinese science and engineering graduate students at the University of California, Berkeley were from Taiwan. ${ }^{26}$

But the Taiwanese government made heavy investments in maintaining networks of professional contact with Taiwanese talent that departed for Japan and the United States, incentivizing workers to eventually return to Taiwan. ${ }^{27}$ Perhaps their most spectacular success story is that of Morris Chang, who earned his Ph.D. at Stanford and worked at Texas Instruments for 25 years before returning to Taiwan in the mid-1980s and founding the 
Box 2, continued.

Taiwan Semiconductor Manufacturing Company (TSMC) - today the most valuable semiconductor company in the world. ${ }^{28}$ In 1998, 109 out of 222

firms in Taiwan's Hsinchu Science Park were founded by returnee entrepreneurs educated and trained in the United States. ${ }^{29} \mathrm{H}$ sinchu has since become one of the largest hubs for semiconductor manufacturing talent in the world.

The return of talent trained abroad played a similarly important role in Japan and especially South Korea, which also built domestic semiconductor industries from scratch. And, as will be discussed in Chapter 3, talent attraction is a crucial part of China's current efforts to indigenize semiconductor supply chains.

\section{Mapping the U.S. Semiconductor Workforce}

This chapter examines features of the current U.S. semiconductor workforce and pipelines into that workforce. The first section of the chapter defines the semiconductor workforce and documents broad industry trends toward employing fewer but higher-skilled workers. The second section examines what proportion of these workers are foreign-born and by what pathway foreign-born workers enter the U.S. semiconductor workforce. The third and final section breaks down educational requirements and talent sources across different parts of the semiconductor supply chain.

\section{Identifying and Analyzing the Semiconductor Workforce}

This report focuses on the high-skilled and technica/subset of the broader semiconductor workforce. This subset excludes workers such as parts assemblers and processors, as well as less those in sales and law. The Appendix provides more methodological detail on how we defined and coded as "high-skilled technical" workers.

High-skilled technical talent is essential to advancing state-of-the-art semiconductor technology. Non-technical workers, while important, are unlikely to play a key role in driving semiconductor innovation. Moreover, the Bureau of Labor Statistics predicted a 10.6 percent decline in absolute employment numbers in the industry between 2018 and 2028, with job 
losses concentrated in low-skilled areas susceptible to automation. ${ }^{30}$ Among high-skilled technical workers, BLS projected job losses of 5 percent on average, with only industrial engineers enjoying significant employment growth. ${ }^{31}$ Overall, BLS predicted a shrinking U.S. semiconductor workforce with a larger proportion of high-skilled workers.

Since the BLS forecasts were published, policymakers and industry have pushed to move more advanced semiconductor R\&D and manufacturing facilities to the United States. ${ }^{32}$ It is unclear how these policies, if implemented, would affect the labor market. On balance, the emphasis on state-of-the-art foundries in these policy proposals suggests they would boost domestic demand for high-skilled workers able to work at the technology frontier. From an innovation and national security perspective, high-skilled workers should therefore occupy a central place in a U.S. semiconductor workforce agenda.

To study the high-skilled technical workforce ("workforce" below), we utilized data from six different sources. Due to measurement and definitional difficulties, different data sources each have their own strengths and weaknesses. For example, BLS tabulations of the total U.S. semiconductor workforce exclude about 56,400 people employed by "fabless" semiconductor firms-almost a quarter of the total workforce as estimated by the Semiconductor Industry Association. ${ }^{33}$ Our data sources are listed in Box 3 ; the Appendix discusses measurement issues in more detail.

Bearing in mind the definitional and measurement challenges discussed above, the next sections highlight important features and trends in the "highskilled technical" semiconductor workforce.

\section{Box 3. Data sources analyzed in this report}

- The Census Bureau's American Community Survey was used to tabulate high-skilled U.S. semiconductor workers' places of origin (Figure 1, Appendix B).

- The World Intellectual Property Organization's database of patent holders' migration flows was used to estimate the inflow and outflow of electrical engineering inventors across countries (Figure 2).

\footnotetext{
* The BLS projections concern the "semiconductor and other component manufacturing" industry, which includes a large number of jobs outside of the semiconductor industry. Semiconductor-specific forecasts are not available (see Appendix for a discussion of data gaps).
} 
Box 3, continued.

- The Department of Education's Integrated Postsecondary Education Data System and the National Science Foundation's Survey of Graduate Students and Postdoctorates in Science and Engineering were used to tabulate graduates and enrollments in semiconductor-related fields at U.S. universities (Table 2, Figure 3).

- The National Science Foundation's Survey of Earned Doctorates was used to analyze intention-to-stay rates among international Ph.D. graduates in semiconductor-related fields (Figure 4). ${ }^{34}$

- The Department of Labor's Permanent Labor Certification Details Database ("PERM"), which tracks green card applicants, was used to assess educational and national backgrounds of applicants sponsored by semiconductor firms (Figures 6 and 7, Appendix C).

\section{A Large and International Workforce}

CSET's coding of high-skilled occupations, detailed in Appendix B, identifies approximately 220,000 high-skilled technical workers in the "electronic components and products" industry, which includes most of the semiconductor industry as well as adjacent industries. Of these workers, approximately 90,000 (41 percent) are either non-citizens or naturalized citizens born outside the United States (Figure 1). India alone is the source of around 21,800 workers ( 10 percent), of whom 15,200 were non-citizens and 6,600 were naturalized. China follows with roughly 12,000 workers (5 percent), split almost equally among non-citizens and naturalized citizens. 
Figure 1. Number of high-skilled workers in the U.S. "electronic components and products" industry by place of origin, 2012-2016.

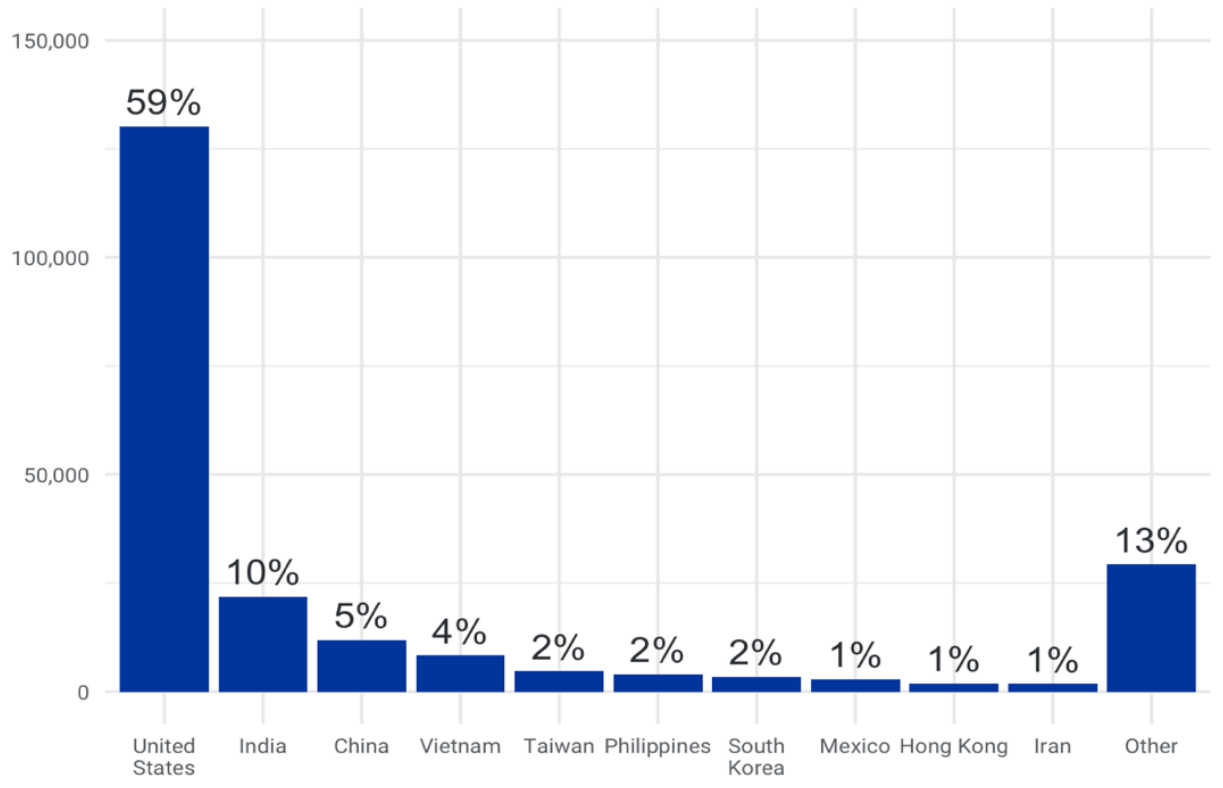

Source: CSET analysis of American Community Survey data.

The importance of international talent to the United States' semiconductor industry is also visible in patent statistics. In 2011 , for example, 87 percent of semiconductor patents awarded to the top 10 patent-producing American universities had at least one foreign-born inventor. ${ }^{35}$ Figure 2 shows the number of electrical engineering patent holders who migrated into or out of major sending and receiving countries. More than 100,000 innovators in electrical engineering migrated to the United States between 2000-2010, far more than migrated to any other nation-a stark contrast with China and India, which lost tens of thousands of patent holders over the same period. 
Figure 2. Inflow and outflow of electrical engineering patent holders by place of origin, 2000-2010.

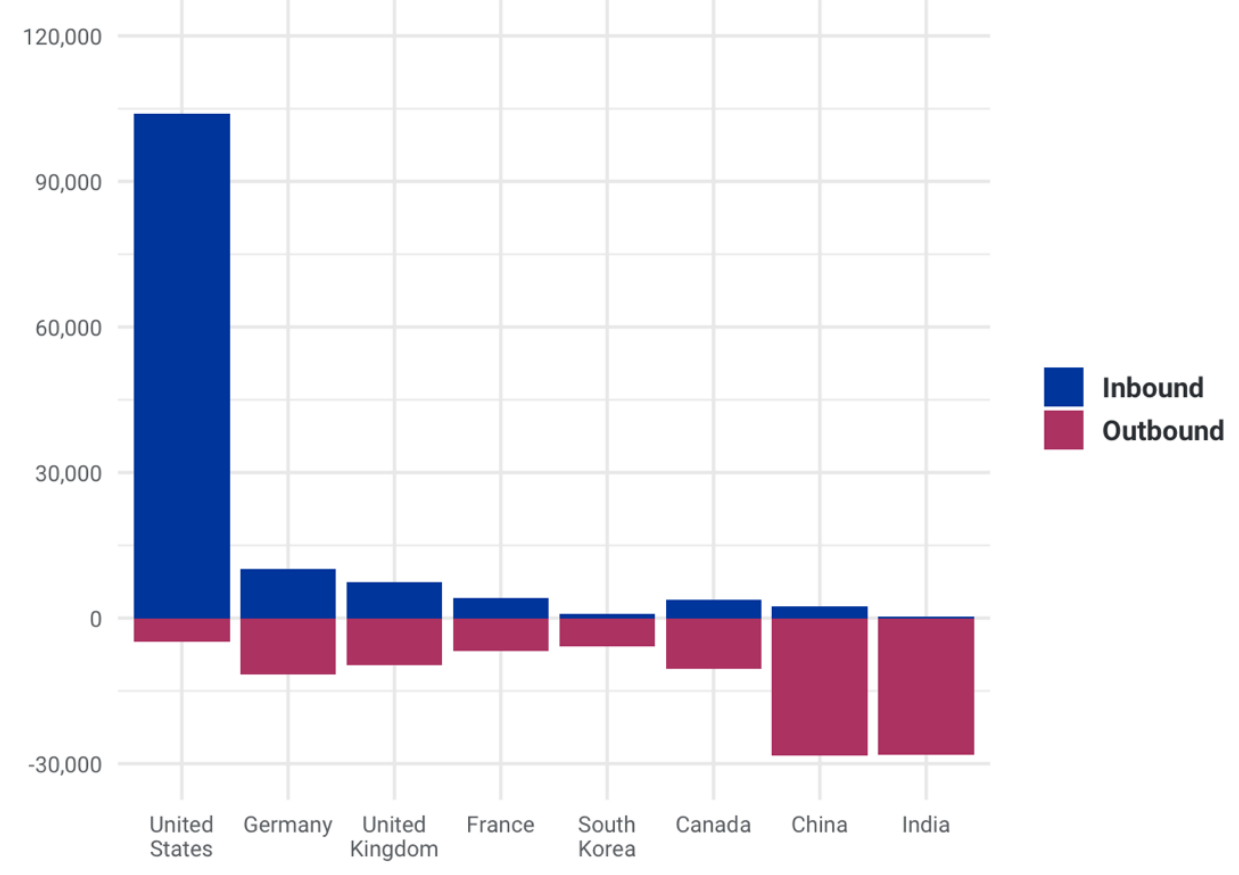

Source: CSET analysis of World Intellectual Property Organization data. ${ }^{36}$

In short, the U.S. semiconductor industry benefits from tremendous inflows of foreign-born high-skilled talent. But how do so many foreign-born semiconductor workers make their way into the U.S. labor force in the first place? The next section turns to this question.

\section{The University Talent Pipeline}

American universities appear to be a vital pathway into the U.S. semiconductor workforce. They provide both training and, for foreign talent, an initial entry point into the country. Firms understand the key role universities play in providing them with high-skilled foreign-born workers: Patrick Duffy, a human resources attorney for Intel, testified as early as 2003 that the "vast majority of the H-1B workers we sponsor are educated at U.S. universities." ${ }^{37}$

This aligns with CSET analysis of more recent green card data, spanning the 2010-2018 period. Among technical workers sponsored for permanent residency by U.S. semiconductor firms over that period who hold a master's or doctoral degree, 62 percent earned their highest educational credential at an American university. ${ }^{38}$ According to data from the Department of 
Homeland Security, more than half of those approved for new $\mathrm{H}-1 \mathrm{~B}$ visas in 2018 were previously on a student visa. ${ }^{39}$

One attractor for these international students is the quality of U.S. universities in semiconductor-related fields. ${ }^{\dagger}$ American universities are highly ranked across the five most important academic disciplines feeding into the semiconductor industry (Table 1). For example, half of the top 50 electrical and electronics engineering programs in the world, and eight of the top 10, are located in the United States.

Table 1. Number of American universities among global top 50 and top 10 rankings for semiconductor-relevant academic fields, 2019.

\begin{tabular}{|l|c|c|}
\hline & U.S. universities in top 50 & U.S. universities in top 10 \\
\hline Electrical and electronics engineering & 25 & 8 \\
\hline Computer science and engineering & 20 & 7 \\
\hline Mechanical engineering & 19 & 6 \\
\hline Chemical engineering & 20 & 8 \\
\hline Materials science and engineering & 21 & 6 \\
\hline
\end{tabular}

Source: Shanghai Academic Ranking of World Universities. ${ }^{40}$

Table 2 shows how many international students graduated from semiconductor-related programs at U.S. universities in the 2016-2017 academic year. The data shows a high proportion of international students at the graduate level in key feeder fields. Indeed, in both computer science and electrical, electronic, and computer engineering-the two most common academic backgrounds for semiconductor workers in the green card datanearly three quarters of master's graduates are international students. In fields like chemistry, physics, and mechanical engineering, these percentages are somewhat lower (around or less than half).

\footnotetext{
t See the next section for analysis of the key feeder fields for the semiconductor industry.
} 
Table 2. Number and proportion of degrees granted to international students in semiconductor-related fields, 2016-2017.

\begin{tabular}{|c|c|c|c|c|c|c|}
\hline & \multicolumn{2}{|c|}{ Bachelor's degrees } & \multicolumn{2}{|c|}{ Master's degrees } & \multicolumn{2}{|c|}{ Doctoral degrees } \\
\hline & $\begin{array}{l}\text { Total } \\
\text { recipients }\end{array}$ & $\begin{array}{l}\text { Percent } \\
\text { foreign }\end{array}$ & $\begin{array}{l}\text { Total } \\
\text { recipients }\end{array}$ & $\begin{array}{l}\text { Percent } \\
\text { foreign }\end{array}$ & $\begin{array}{l}\text { Total } \\
\text { recipients }\end{array}$ & $\begin{array}{l}\text { Percent } \\
\text { foreign }\end{array}$ \\
\hline $\begin{array}{l}\text { Computer and Information } \\
\text { Sciences/Programming/ } \\
\text { Computer Systems Analysis }\end{array}$ & 56,090 & $8 \%$ & 33,437 & $73 \%$ & 1,752 & $59 \%$ \\
\hline $\begin{array}{l}\text { Electrical, Electronics, and } \\
\text { Communications } \\
\text { Engineering/ } \\
\text { Computer Engineering }\end{array}$ & 28,645 & $12 \%$ & 18,787 & $74 \%$ & 2,686 & $48 \%$ \\
\hline $\begin{array}{l}\text { Mechanical Engineering/ } \\
\text { Mechatronics }\end{array}$ & 35,780 & $9 \%$ & 8,542 & $53 \%$ & 1,507 & $56 \%$ \\
\hline $\begin{array}{l}\text { Physics/Engineering } \\
\text { Physics }\end{array}$ & 8,508 & $8 \%$ & 2,006 & $38 \%$ & 1,909 & $45 \%$ \\
\hline $\begin{array}{l}\text { Chemistry/ } \\
\text { Chemical Engineering/ } \\
\text { Materials Science/ } \\
\text { Materials Engineering }\end{array}$ & 28,903 & $8 \%$ & 5,650 & $44 \%$ & 4,761 & $42 \%$ \\
\hline Total & 157,926 & $9 \%$ & 68,422 & $67 \%$ & 12,615 & $48 \%$ \\
\hline
\end{tabular}

Source: CSET analysis of 2016-17 Integrated Postsecondary Education Data System (IPEDS).

The number of international students in these programs is at a record high.

Figure 3 shows a significant increase in the number of international students in electrical engineering and computer science graduate programs, the two biggest feeder disciplines for the semiconductor industry. While the number of international students in these graduate programs has more than doubled since 1990, the number of American students has remained flat. 
Figure 3. Number of domestic and international students enrolled in semiconductor-related graduate programs at U.S. universities, 1990-2018.

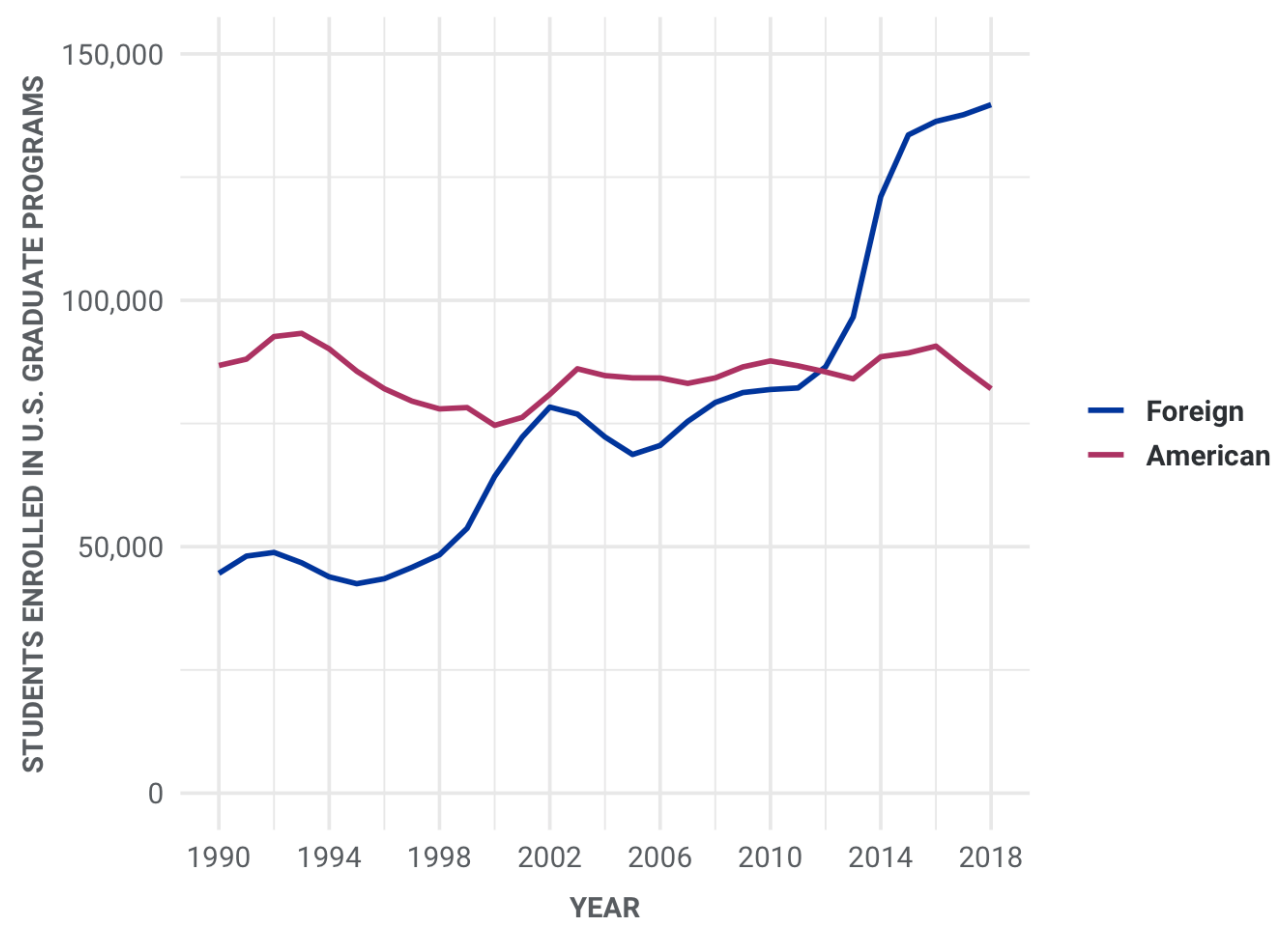

Source: NSF Survey of Graduate Students and Postdoctorates in Science and Engineering. Data includes students in Electrical, Electronics and Communications Engineering and Computer Science.

Not only do foreign nationals make up the majority of graduate students in U.S. feeder disciplines, they also stay within the United States at high rates after graduating (Box 4). The large number of international students in U.S. graduate programs is thus consistent with the large number of foreign-born workers in the U.S. semiconductor workforce as a whole. 
Box 4: Stay rates among international graduates of U.S. universities.

NSF surveys of doctoral graduates in electrical, electronics, and communications engineering suggest that the overwhelming majority of students who get Ph.D. degrees from U.S. universities intend to stay in the country following graduation (Figure 4). Intention-to-stay rates are particularly high for Indian and Chinese graduates. Rates among Chinese graduates decreased slightly between 2002 and 2011 , from roughly 97 to 90 percent, but were stable between 2011 and 2017. Rates among Indian workers have remained steady around or above 90 percent throughout this period.

Figure 4. Percent of international graduates from semiconductor-relevant U.S. Ph.D. programs with plans to remain by place of origin, 2002-2017.

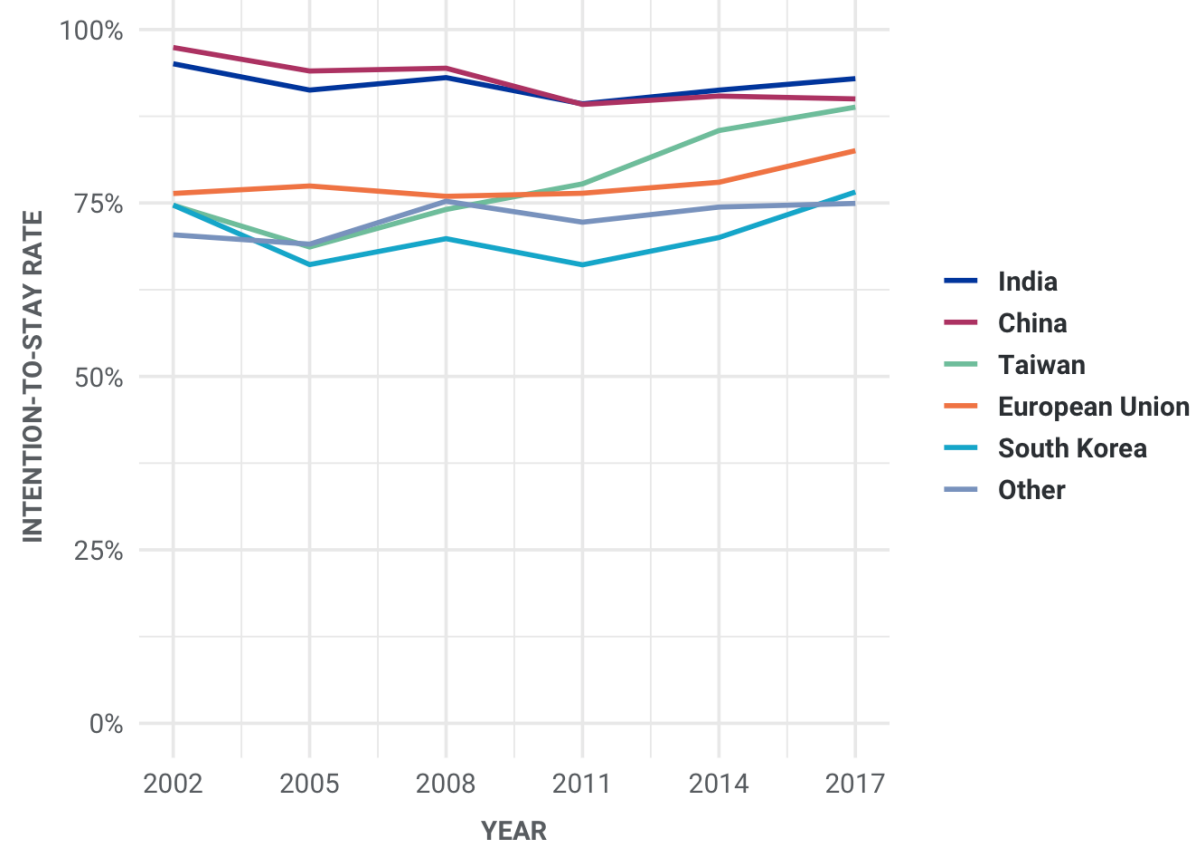

Source: NSF Survey of Earned Doctorates. Data includes Ph.D. graduates in computer science and in chemical, electrical, electronics, communications, industrial, mechanical, and computer engineering.

A 2018 report by the Oak Ridge Institute for Science and Education explored stay rates among doctoral recipients five and 10 years after they graduated from American universities. ${ }^{41}$ Its results align well with the intention-to-stay rates presented in Figure 5. Among international graduates who earned their doctoral degrees between 2007 and 2009, it found a five-year post-graduation stay rate of 76 percent among engineering 
Box 4, continued.

graduates and 77 percent among computer science and mathematics graduates. The report also highlighted variation by place of origin: the highest stay rates were among Chinese and Indian graduates, of whom 86 percent remained in the United States 10 years after graduation.

\section{Talent Across the Semiconductor Supply Chain}

Given that U.S. universities play a crucial role in attracting and developing semiconductor workers, how might policymakers strengthen the semiconductor training pipeline? In particular, which academic feeder disciplines should policy target? This section shows that the relevant disciplines vary across different parts of the complex semiconductor supply chain, implying that a narrow approach to attracting and developing semiconductor talent would be shortsighted. As the supply chain evolves, different academic backgrounds can become more or less important to the health of U.S. firms.

This report focuses on firms in four key parts of the supply chain: Electronic Design Automation (EDA) developers, chip design ("fabless") firms, chip manufacturers ("fabs"), and Semiconductor Manufacturing Equipment (SME) suppliers (see Figure 5 for a supply chain schematic). ${ }^{\dagger}$ This leaves out workers conducting research in academia and employees at materials suppliers, assembly, test, and packaging firms, and distributors. These parts of the supply chain either are not centers of technical talent or are not tracked in the workforce data sources used in this paper.

\footnotetext{
* Stay rates for Chinese and Indian graduates are available only aggregated across all science and engineering fields, which includes fields that have lower stay rates on average than engineering and computer science.

${ }^{\dagger}$ As their names imply, EDA developers supply design automation tools to chip designers, while SME suppliers supply equipment to chip manufacturers. Both EDA and SME require highly sophisticated semiconductor R\&D; neither designers nor manufacturers could function without these suppliers.
} 
Figure 5. The semiconductor supply chain

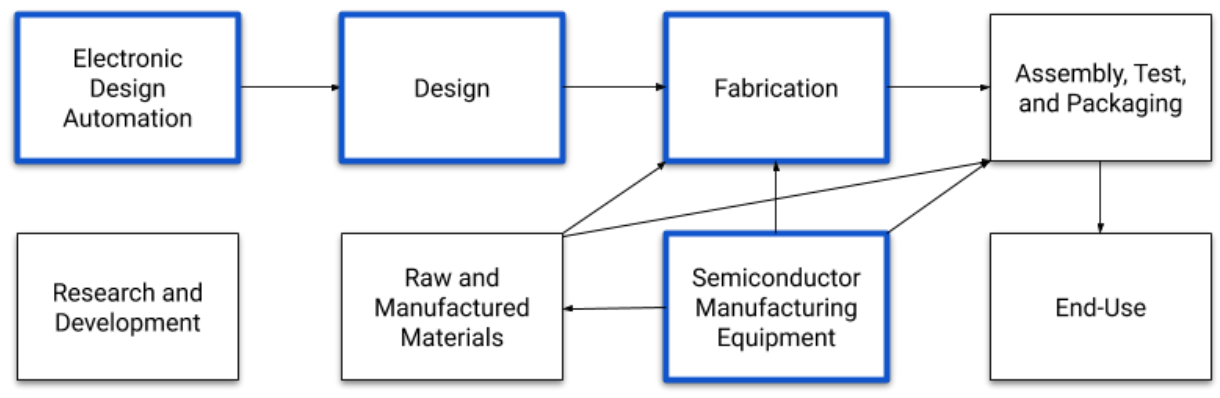

Source: Chart prepared by Saif M. Khan. Bolded boxes represent parts of the supply chain focused on in this paper.

To identify the major academic feeder disciplines, we selected one to three of the biggest U.S. firms in each of the supply chain parts. We then used Department of Labor data on U.S. green card applicants, a data source that has both employer and degree data, to identify applicants sponsored by these firms and analyze their educational backgrounds. The results, summarized in Table 3 and Figure 7, show both similarities and differences in knowledge and skill demands from one part of the supply chain to the next. A more detailed discussion of the data source and firm-specific analysis is presented in Appendix C.

\footnotetext{
* Green card data describes the most in-demand technical roles across different parts of the supply chain, because firms typically do not sponsor green card applications unless they have capacity needs that cannot be filled by workers with American citizenship. This data is the only public source we were able to find that has both employer names and employee fields of study. Readers should bear in mind that all of the individuals in the data are non-U.S. citizens. The results highlight fields where each part of the supply chain has the greatest need in terms of human capital, but may underestimate the prevalence of educational backgrounds from which there is already a significant supply of qualified American workers. Additionally, this analysis only considered the top firms in each part of the supply chain. The results do not appear highly sensitive to the inclusion or exclusion of a given larger firm (see Appendix C), but the largest firms may differ from smaller firms in a number of ways. For example, larger firms likely have more capacity to sponsor green card applications for more junior roles. It is unclear whether or how this biases the feeder discipline results.
} 
Table 3. Major firms and top feeder disciplines among green card applicants across the semiconductor supply chain.

\begin{tabular}{|l|l|l|l|l|}
\hline & Chip Design & $\begin{array}{l}\text { Electronic Design } \\
\text { Automation }\end{array}$ & Chip Foundries & $\begin{array}{l}\text { Semiconductor } \\
\text { Manufacturing } \\
\text { Equipment Suppliers }\end{array}$ \\
\hline Definition & $\begin{array}{l}\text { Develop new } \\
\text { designs for } \\
\text { transistor layout }\end{array}$ & $\begin{array}{l}\text { Develop software } \\
\text { for automating } \\
\text { chip design }\end{array}$ & $\begin{array}{l}\text { Manufacture } \\
\text { integrated circuits } \\
\text { in high volume }\end{array}$ & $\begin{array}{l}\text { Develop sophisticated } \\
\text { machinery for use in chip } \\
\text { fabs }\end{array}$ \\
\hline $\begin{array}{l}\text { Major U.S. firms } \\
\text { Qroadcom, }\end{array}$ & $\begin{array}{l}\text { Synopsys, } \\
\text { Cadence, Mentor } \\
\text { Graphics }\end{array}$ & $\begin{array}{l}\text { GlobalFoundries } \\
\text { applicants at } \\
\text { major U.S. firms }\end{array}$ & $\begin{array}{l}\text { Applied Materials, KLA- } \\
\text { Tencor, and Lam } \\
\text { Research }\end{array}$ \\
\hline $\begin{array}{l}\text { Top academic } \\
\text { feeder } \\
\text { disciplines } \\
\text { among green } \\
\text { card applicants }\end{array}$ & $\begin{array}{l}\text { Electrical } \\
\text { engineering and } \\
\text { computer science }\end{array}$ & $\begin{array}{l}\text { Electrical, } \\
\text { computer } \\
\text { engineering }\end{array}$ & $\begin{array}{l}\text { Electrical, } \\
\text { electronic, } \\
\text { computer, and } \\
\text { mechanical } \\
\text { engineering }\end{array}$ & $\begin{array}{l}\text { Mechanical and } \\
\text { electronic engineering, } \\
\text { chemistry and chemical } \\
\text { engineering }\end{array}$ \\
\hline
\end{tabular}

\section{Chip Design}

Chip design firms like Broadcom, Qualcomm, and Nvidia are responsible for developing the designs that make it possible to pack ever more transistors onto a single wafer and meet application-specific needs. These designs are highly valuable: a specialized chip design might generate hundred- or even thousand-fold increases in energy efficiency and speed relative to a generic design. ${ }^{42}$ Design firms build chip architectures that not only seek to maximize transistor density, but also to ensure logical correctness and efficient routing of signals, all while adhering to highly complex rules governing which designs are and are not possible to manufacture. Among green card applicants in our sample who listed their educational background, almost three quarters had a

\footnotetext{
* These totals are the number of technical green card applicants sponsored by the one to three major U.S. firms identified as representative of each part of the supply chain. They are included to show the size of the samples used to generate Figure 6 . They do not reflect the proportion of workers across the U.S. semiconductor workforce as a whole. For example, the three chip design firms in our sample sponsored 3,916 green card applicants-more than all of the other firms in our sample combined-but design workers likely make up just 20 percent of all semiconductor workers. See Appendix C for a more detailed breakdown of green card application data.
} 
background in electrical, electronics, and computer engineering, and another 13.2 percent had a background in computer science (Figure 6).

Figure 6. Field of highest degree among green card applicants across the supply chain.

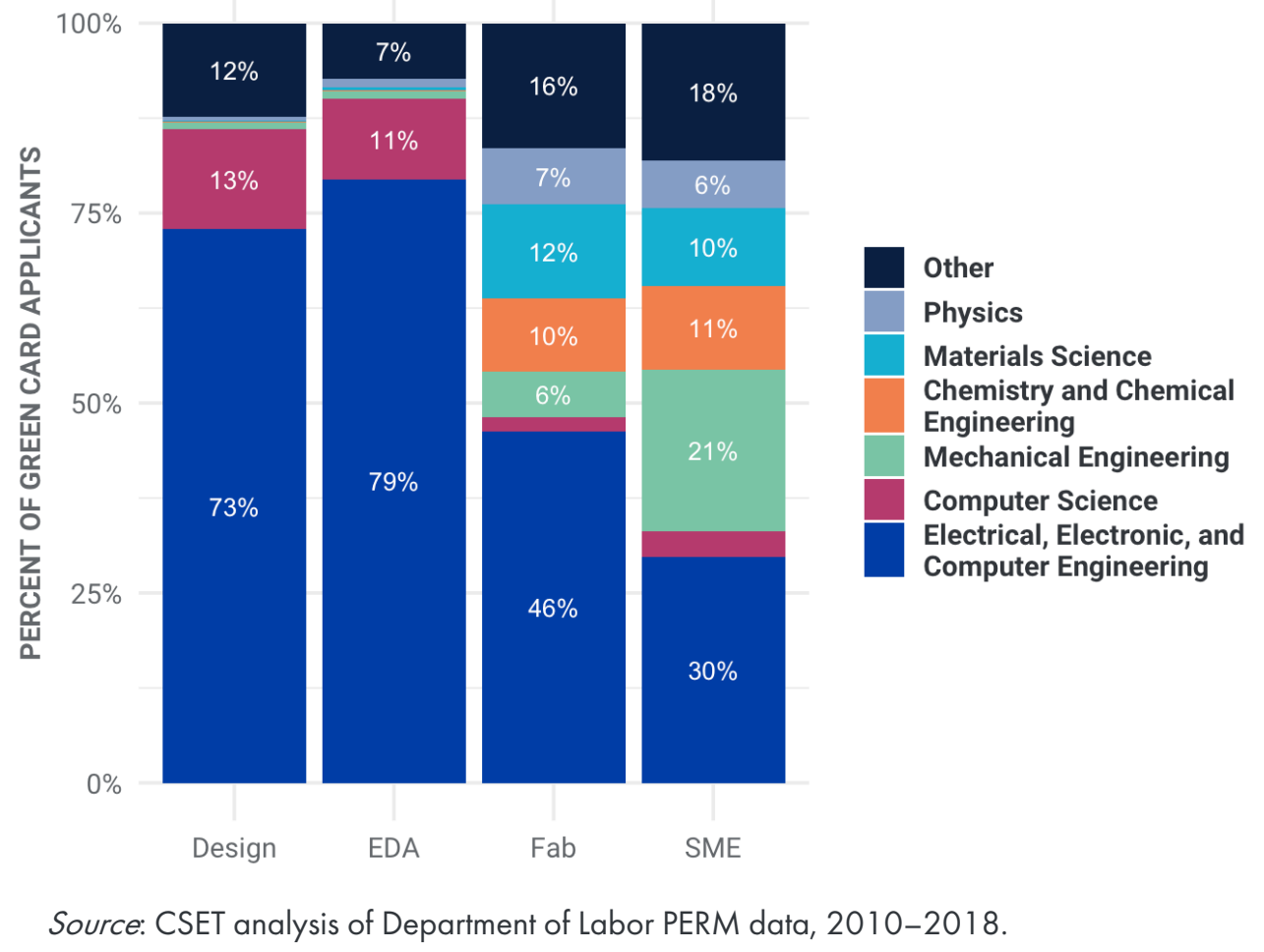

\section{Electronic Design Automation}

With potentially billions of transistors in a single modern computer chip, mapping out each transistor by hand is impossible. This is particularly so because, as transistor density has risen, the rules governing what is possible to manufacture have become much more complex. Electronic design automation firms like Synopsys, Cadence, and Mentor Graphics write software tailored to the needs of semiconductor design firms, which accounts for these rules and allows designers to focus on higher-level architectural decisions. Like chip designers, EDA workers predominantly have backgrounds in electrical, electronic, and computer engineering (Figure 6).

\section{Fabrication}

Front end fabrication plants or "fabs" are typically run by the largest firms in the semiconductor industry, because building and operating a leading-edge 
plant requires tens of billions of dollars. ${ }^{43}$ U.S. firm GlobalFoundries, Taiwan's TSMC, and China's SMIC are examples. Technical roles at foundries vary considerably and may require knowledge of chip design, semiconductor manufacturing equipment, process management, or test development. In line with this, green card applicants in our data who listed their educational background came from a greater range of academic disciplines than those seen at chip design and EDA firms, including a larger proportion of materials science and engineering backgrounds (Figure 6).

\section{Semiconductor Manufacturing Equipment (SME) Suppliers}

Each step of the semiconductor manufacturing process requires highly sophisticated equipment, most of which foundries purchase from suppliers. The most advanced photolithography "scanners," for example, are used to layer circuit designs onto the surface of a wafer with nanometer-scale precision. Scanners are among the most costly and complex manufacturing devices in the world, with the most expensive selling at more than \$100 million per unit. ${ }^{44}$ Building such scanners often requires advanced knowledge of topics such as optical modeling and design theory, lasers, and polarization. Once the scanner is finished tracing its patterns into a wafer, those patterns are etched into the wafer using specialized etching equipment from another supplier. Green card applicants sponsored by SME firms had much more varied backgrounds than applicants sponsored by EDA and design firms-about half the workforce is split across physics, materials science, chemistry, and mechanical engineering, while less than a third were trained in electrical engineering (Figure 6).

\section{Points of Origin Across the Supply Chain}

While an analysis of American Community Survey (ACS) data demonstrated clearly the importance of foreign talent across the industry, it left out key parts of the supply chain. Green card applicant data makes this analysis possible. The data, presented in Figure 7, shows that Indian workers make up at least a plurality across all parts of the supply chain examined; Chinese workers also make a strong showing. Indians are especially dominant in design and EDA firms, comprising almost two thirds of all green card applicants in those areas. Outside of China and India, workers are divided across many points of origin, though South Koreans and Taiwanese show up in significant numbers across multiple parts of the supply chain, just as they did in the aggregate ACS data. 
Figure 7. Points of origin among green card applicants at semiconductor firms, by segment of the supply chain.

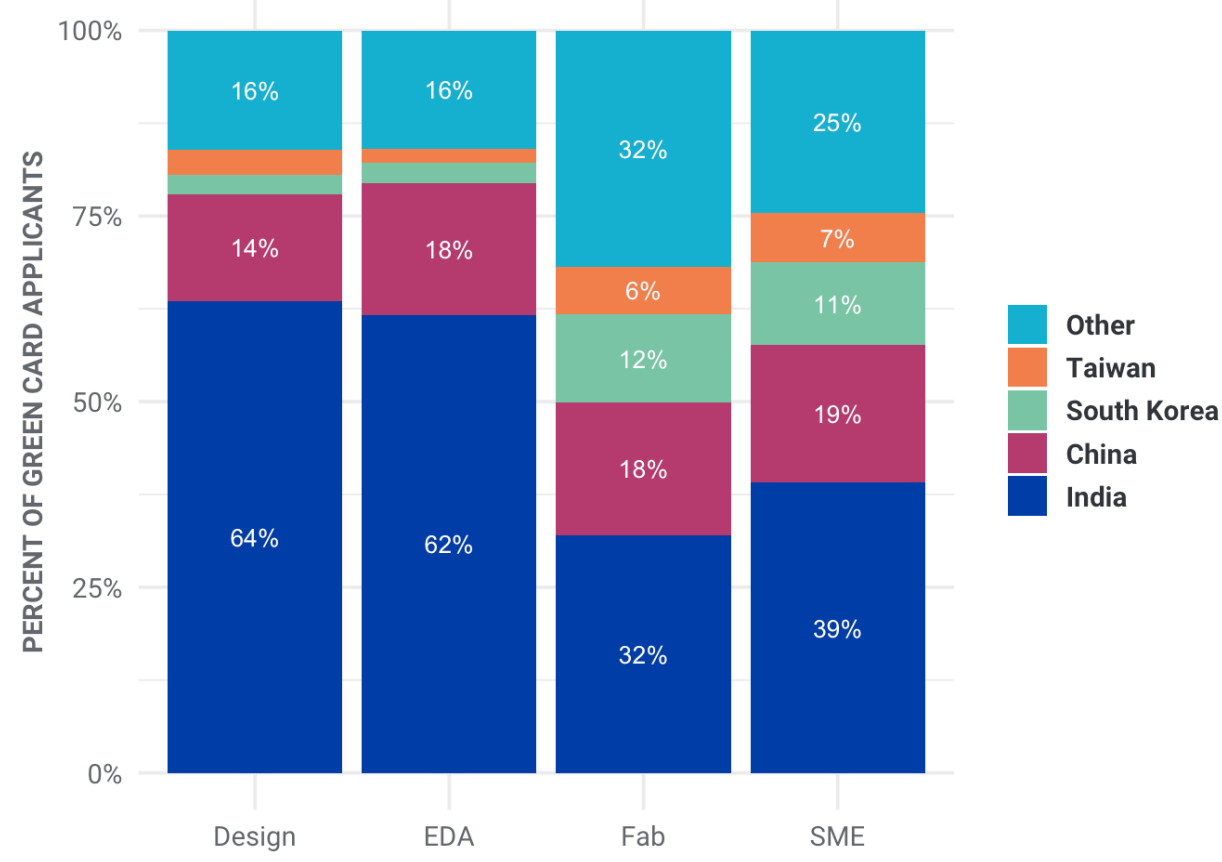

Source: CSET analysis of Department of Labor PERM data, 2010-2018.

One difference between the green card data and ACS data is that Indian workers make up an especially large proportion of green card applicants, particularly in design and EDA firms. This partly reflects broader immigration trends: Indians are heavily overrepresented in both $\mathrm{H}$-1B and green card pipelines, in part because country-based caps lead to delays in naturalization among many Indian immigrants (see Chapter 4). More detailed point-oforigin analysis, breaking down by specific firms, is presented in Appendix C.

\section{Semiconductor Workforce Policy}

Talent is one of the most important sources of U.S. semiconductor leadership. Maintaining that leadership will require training and retaining both domestic and international semiconductor workers, while also guarding against the international transfer of important semiconductor technology. Balancing these two priorities will not be easy. On the one hand, foreign-born scientists and engineers are hugely important to the U.S. semiconductor industry; the United States could not have obtained, nor can it now maintain, its leadership position without international talent. On the other hand, international talent is also one of the main vectors by which semiconductor technology spreads to 
other countries, potentially creating or strengthening competitors to U.S. semiconductor companies.

Yet this balance, while difficult, is not impossible to strike. Protection and promotion can and should go hand in hand; advancing technological progress is ultimately the surest route to protecting the United States' leadership position. Drawing on the findings presented in the previous chapter, the sections below discuss the semiconductor workforce goals U.S. policymakers should pursue and what policy tools they could use in doing so.

\section{Protect: Preventing International Technology Transfer}

The Chinese government has invested billions in building up its domestic semiconductor industry, with plans going back decades. ${ }^{45}$ And China recognizes-as Japan, South Korea, and Taiwan did in the past (Box 2)-that international talent recruitment can make or break these efforts. Since much of the most important semiconductor knowledge is tacit in nature, it can only be transferred through the movement of skilled individuals. For now, despite decades of investment, China's shortage of talent remains a key barrier to growth of the country's semiconductor industry. One assessment in 2017 put China's semiconductor labor needs by 2020 at more than 700,000, but noted that the country at the time only had between 300,000 and 400,000 qualified workers. ${ }^{46}$

\section{Safeguarding Domestic Technology}

The possibility that U.S.-trained talent could help China develop its semiconductor industry has policymakers worried. Both Congress and federal agencies have launched investigations into Chinese talent recruitment programs, which, they argue, can incentivize harmful or illegal intellectual property theft. ${ }^{47}$ The White House is concerned that Chinese companies' ability to pay subsidized above-market compensation to semiconductor talent will make scientists and engineers "a key conduit for technology transfer from the United States to China." ${ }^{48}$ Most of these worries are focused on Chinese citizens based in the United States, although China also targets non-Chinese engineers for recruitment. ${ }^{49}$ According to our analysis, approximately 5.5 percent of high-skilled U.S. technical workers in semiconductor-related industries were born in China. That translates into about 12,000 workers, half of whom are now naturalized U.S. citizens (Figure 2). 
However, China has so far struggled to attract talent from the United States. Around 90 percent of Chinese graduates from U.S. universities who got their Ph.D. in semiconductor-related fields intend to stay in the country after graduating (Box 4). ${ }^{50}$ And those who do return to China do not necessarily stay there. James A. Lewis, an expert at the Center for Strategic and International Studies and a former senior official of the State and Commerce Departments, notes in a paper on China's semiconductor ambitions that many recruits leave the country again after a year or two. He calls China's talent programs "good at recruitment, bad at retention." 51 Senior Chinese advisors echo this assessment, and talk about a "migration deficit" negatively affecting the country's industrial goals (see also Figure 3). ${ }^{52}$ This does not imply there are no risks: as discussed in Box 2, a small number of high-caliber returnees, combined with an ample supply of domestic STEM graduates, were sufficient to seed a world-class semiconductor manufacturing industry in Taiwan. But there are also clear benefits to U.S. competitiveness from the current flow of talent between the United States and China.

U.S. policymakers should take these advantages into account when crafting policies aimed at minimizing technology transfer risk. Large reductions in the flow of talent between China and the United States would likely be welcomed by Chinese policymakers. And reductions in talent flow are also not guaranteed to reduce technology transfer. Studies show that semiconductor companies may respond to restrictions on foreign talent in the United States by moving some of their work abroad, ${ }^{53}$ where know-how and technology could in fact be at higher risk of being transferred and where technology is at greater risk of sabotage. Talent-centered counter-transfer policies that seem attractive at first glance could easily backfire by facilitating China's talent recruitment goals or harming U.S. supply chain security. 
Measures to protect domestic semiconductor technology should therefore be narrow and targeted. In protecting that technology, most attention should be paid to the private sector. ${ }^{*}$ Semiconductor companies already take extensive measures to protect the valuable intellectual property and tacit know-how central to their business models. ${ }^{54}$ But government also has a role to play.

The three most immediate tools the U.S. government has to screen and monitor private sector employees are visa policy, administered by the Department of State; "deemed" export licensing, which governs the transfer of controlled information to foreign nationals within the United States, administered by the Department of Commerce; and trade secret and economic espionage investigations, led by the Department of Justice. ${ }^{55}$ Each of these tools, if used judiciously, can help protect semiconductor and other kinds of technology from individuals with malicious intent. Narrow talentfocused policies should be paired with other counter-transfer measures, such as screening foreign investments in semiconductor companies, pushing for stronger patents and trade secrets regimes abroad, and enhancing cyber protections. Compared to policies focused on restricting talent, these measures could yield more technology protection with fewer risks of backfiring. ${ }^{56}$

\section{Collaborating with Allies and Partners}

Protection against technology transfer will also require greater international coordination with allies and partners. Because the semiconductor industry is highly concentrated, the list of relevant talent hubs is short: the biggest companies are headquartered in South Korea, Taiwan, and Japan, and firms headquartered in the Netherlands and the United Kingdom are also leaders in specific parts of the supply chain. China has and will continue to target semiconductor talent and technology in each of these places. Workers from

\footnotetext{
* Because most semiconductor innovation is incredibly resource-intensive, barriers to entry in the industry are high and know-how gained in an academic setting does not easily translate into commercial success. This is one reason that semiconductor companies have historically been able to collaborate on what they call "pre-competitive" research in initiatives like SEMATECH, while competing viciously for market share through applied R\&D. Protecting academic R\&D is more important in technology areas where barriers to entry are lower and where it takes fewer resources to translate fundamental research advances into commercial or military gains. For more background on the relationship between academic research and innovation, and on how this relationship differs across sectors, see David C. Mowery, Richard R. Nelson, Bhaven N. Sampat, and Arvids A. Ziedonis, Ivory Tower and Industrial Innovation: University-Industry Technology Transfer Before and After the Bayh-Dole Act (Stanford, CA: Stanford University Press, 2004).
} 
Taiwan are most intensely targeted because of Taiwan's geographic and linguistic closeness to China. Media reports suggest that nearly 10 percent of Taiwanese semiconductor engineers have been recruited by China, although experts consider this number inflated. ${ }^{57}$

The U.S. government has already begun engaging in bilateral and multilateral conversations on technology transfer. ${ }^{58}$ But more will need to be done to counteract the pressures that even allied countries and their companies face to compete with each other for Chinese talent and resources. ${ }^{59}$ This will likely include offering material incentives, such as joint R\&D activities, as part of greater collaboration on counter-transfer activities. ${ }^{60}$ Ultimately, it is only with positive investments that China's governmentsubsidized compensation packages can be countered effectively.

\section{Promote: Strengthening the Semiconductor Workforce}

American companies have long been dominant across many segments of the semiconductor supply chain, in large part the result of their ability to recruit and retain top scientists and engineers. This dominance, along with the excellence of U.S. research universities, helps attract and train the next generation of talent. Maintaining this virtuous cycle is key to sustaining a successful semiconductor workforce.

\section{Investing in Education and Research}

Policymakers have a number of options for growing the domestic workforce; this report highlights education and research investments in particular. Research investments have historically been important in domestic workforce development. For example, initiatives like SEMATECH, a consortium jointly funded by government and industry in the 1980s and 1990s, incubated many top semiconductor engineers and scientists. ${ }^{61}$

Universities are a key pipeline for both domestic and international semiconductor talent. As noted above, most foreign-born semiconductor workers first came to the United States as students, and American institutions account for a majority of the global top 10 universities in semiconductorrelated fields (Table 1). Domestic enrollment in semiconductor-related

\footnotetext{
* Other policy options include loan forgiveness for students working in critical sectors, scholarship-for-service programs that allow students to do their service time teaching or working in critical fields, or tax deductions that incentivize human capital investments by industry just as they currently do for physical infrastructure investments.
} 
graduate programs has been flat since 1990, while international enrollments nearly tripled in that same period, contributing to the U.S. semiconductor industry's reliance on international talent (Figure 4).

Two developments threaten U.S. universities' dominance and, consequently, the country's semiconductor talent pipeline. First, other countries are investing heavily in their educational institutions and, by at least some measures, U.S. universities have fallen in international rankings in relative terms from 2007 to $2016 .{ }^{62}$ Second, budget challenges and travel restrictions related to COVID19 will significantly decrease international enrollments at U.S. universities. ${ }^{63}$ One important priority for policymakers is thus to increase the number of American students who enroll in semiconductor-related graduate programs. ${ }^{64}$

Education and research investments should be targeted broadly across relevant fields within the physical sciences and engineering. While electrical, electronic, and computer engineering is the field most strongly associated with the semiconductor industry among green card applicants, less than half of applicants had EECE degrees in two of the four supply chain segments looked at in this report (Figures 6-9). As the semiconductor industry continues to innovate and specialize, investing in fields like chemistry and chemical engineering, materials science and engineering, and computer science will also be of critical importance. ${ }^{65}$ Experts have long been concerned that U.S. government funding for the physical sciences and engineering has lagged behind that for the life sciences. ${ }^{66}$

Government investments in research and workforce development are often most effective when they involve collaboration with industry. For example, the launch of New York's upstate "Tech Valley" semiconductor and nanotechnology cluster-called "one of the most extraordinary developments in recent U.S. industrial history" ${ }^{167}$-involved joint investments by the state and federal government, public and private universities (e.g., University at Albany - SUNY, Rensselaer Polytechnic Institute), and some of the world's biggest semiconductor and computing companies (e.g., IBM, AMD, Micron Technologies, ASML). ${ }^{68}$ DARPA's recent $\$ 1.5$ billion Electronics Resurgence Initiative similarly involves government-academic-industry partnerships. ${ }^{69}$

Education funding could also be structured to encourage closer academicindustry integration-for example, by incentivizing universities to adopt "coop" or internship models through which students can work at semiconductor companies or in other critical sectors as part of their degree. ${ }^{70}$ The Taiwan Semiconductor Research Institute, funded by the Taiwanese government, 
hosts both cutting-edge semiconductor research and extensive education and training programs for students, including a range of applied and laboratory courses. ${ }^{71}$ Many important technical semiconductor jobs do not require graduate degrees or deep theoretical knowledge. Investments in domestic graduate education should thus go hand in hand with investments in programs that emphasize hands-on engineering and on-the-job training.

Investments in education and research should be measured and sustainable. In the past, rapid and unsustainable spending increases in fields like the life sciences produced gluts of talent and boom-and-bust cycles. ${ }^{72}$ Excess labor supply could contribute to a greater oufflow of talent, exacerbating technology transfer risk. We know of no semiconductor workforce study that assesses future skill and job needs in sufficient detail for targeted planning. ${ }^{73}$ Improvements in data collection on the semiconductor industry and workforce, which we discuss below, would help enable such assessments.

\section{Retaining and Expanding Immigration Pipelines}

The second prong of a U.S. semiconductor workforce promotion strategy is immigration reform. International students make up a large proportion (40 to 75 percent) of graduate students in semiconductor-related fields (Table 2). Virtually all growth in semiconductor-related enrollments at U.S. universities since 1990 has come from international students (Figure 4), and, as the cases of Mohamed Atalla and Dawon Kahng discussed in the introduction illustrate, international talent has been important to U.S. semiconductor leadership from the industry's birth. For this reason, semiconductor companies have identified immigration reform as the "number one [workforce policy] change that would help the industry in the near term." 74

At minimum, keeping the semiconductor industry competitive requires sustaining critical aspects of the current immigration system. Most importantly, the Optional Practical Training program, which allows international STEM students to work in the United States for up to three years after graduating, is under threat from both lawsuits and possible regulatory changes. ${ }^{75}$ Since most high-skilled semiconductor workers initially come to the country by studying at U.S. universities, the OPT program is key to the health of the semiconductor industry. Intel, for example, hires around 1,500 international master's and Ph.D. graduates through OPT each year. This represents 80 percent of all its foreign national hires; due to issues with other immigration programs, the company estimates it "would be able to hire just $30 \%$ of the highly skilled graduates we currently hire" if OPT were eliminated. ${ }^{76}$ The surest way to 
protect OPT would be for Congress to enshrine the program-or some functionally equivalent post-study work visa-into law.

Narrow reforms could also target specific issues with the U.S. immigration system that could support the semiconductor industry. One targeted reform could involve country-based caps on the number of employment-based green cards that can be issued each year. The most common places of origin for foreign-born workers in the semiconductor industry are India and China (Figure 7). . Because the number of green card applicants from these places has long exceeded the number of available slots, Indian and Chinese citizens currently face huge backlogs. For example, for an Indian citizen with a graduate degree who applies for permanent residency today, estimates from a study by the Cato Institute suggest it would take between 39 and 89 years for their application to be processed. ${ }^{77}$ If Congress eliminated country-based caps, this would likely benefit the semiconductor industry. ${ }^{\dagger}$

More ambitiously, policymakers could look beyond maintaining or reallocating the current number of slots and make broader changes to the immigration system. An example of such reforms would be to increase the number of available employment-based green cards or $\mathrm{H}-1 \mathrm{~B}$ visas per year. ${ }^{78}$ The number of available slots in these programs has remained almost unchanged since they were established in $1990 .^{79}$ Such increases could be coupled with review and revision of known issues with the immigration system, such as how prevailing wage calculations are made. ${ }^{80}$ However, such reforms would require large legislative efforts likely to be politically infeasible today..$^{\ddagger}$

\footnotetext{
* Indians make up about 40 percent of green card applicants at U.S. SME firms and more than 60 percent of those at Design and EDA firms and fabs; Chinese citizens account for between 7 and 19 percent of green card applications, depending on the part of the supply chain.

† The "Fairness for High-Skilled Immigrants Act," which passed the House and is currently stalled in the Senate, would remove country-based caps. While the semiconductor industry would likely be a beneficiary, the broader consequences of removing country-based caps are complex, and before taking this step Congress should carefully assess its potential consequences; see, e.g., William A. Kandel, "The Employment-Based Immigration Backlog" (Congressional Research Service, March 2020), https://fas.org/sgp/crs/homesec/R46291.pdf.
}

₹ A detailed analysis of immigration policy options is beyond the scope of this paper. For those interested, the sources cited in this paragraph offer a starting point. 
Effectively pursuing the protection and promotion priorities outlined above will require improved data collection on the U.S. semiconductor workforce. Many policy-relevant questions are currently difficult to answer due to data gaps and incomplete measurement frameworks. For example, as noted in Chapter 3, current semiconductor industry classifications exclude an estimated 25 percent of the semiconductor workforce. ${ }^{81}$ On the protection side, better data on semiconductor students and workers could help track talent flows and, by extension, the potential transfer of valuable technology. On the promotion side, better data on training and hiring pipelines could enable universities and policymakers to invest in programs that align more closely with semiconductor companies' current and future workforce needs.

There are several concrete steps policymakers can take today. First, the North American Industry Classification System (NAICS) codes, coordinated on the U.S. side by the White House's Office of Management and Budget, should be updated to reflect that chip design ("fabless") companies are part of the semiconductor industry. ${ }^{82}$ A reclassification process was started in 2009, but it has not yet been implemented. ${ }^{83}$ Second, the U.S. government currently collects detailed data on post-graduation career and migration choices among Ph.D. graduates and, to a lesser extent, bachelor's graduates. Little is known about master's students, even though they account for more than 85 percent of U.S. graduate students in semiconductor-related fields (Table 2). To better track outcomes for this group-for example, how many international master's students stay in the United States after graduating-Congress should provide the NSF with the mandate and resources to extend its survey portfolio to include master's students. * Deeper analyses of the semiconductor workforce will undoubtedly uncover other data gaps.

\section{Conclusion}

U.S. semiconductor industry leadership is a tremendous economic and strategic asset that drives progress in Al and other critical technologies. But other countries increasingly challenge that leadership position across the

\footnotetext{
*The main NSF surveys that look at Ph.D. graduates' career outcomes are the Survey of Earned Doctorates (SED) and the Survey of Doctoral Recipients (SDR), discussed in Box 4 above. Bachelor's degree holders are surveyed in the National Survey of College Graduates (NSCG). These surveys are coordinated by the NSF's National Center for Science and Engineering Statistics.
} 
supply chain, and a possible end of Moore's Law could make catch-up more feasible in the years ahead.

To remain at the leading edge in key parts of the supply chain, the United States will have to strengthen an enduring advantage: its uniquely broad and deep bench of semiconductor talent. While U.S. firms' demand for lowerskilled semiconductor workers may decrease significantly over the coming decade, demand for higher-skilled workers is likely to increase.

Unfortunately, the supply of American workers with graduate training in semiconductor-relevant disciplines has remained flat. Fortunately, American graduate schools lead the world in semiconductor-relevant fields like electrical engineering and computer science; these programs draw top talent from around the world into American semiconductor firms. And many students stay in the country after graduation, attracted by jobs in vibrant semiconductor talent clusters from Hillsboro, Oregon to the Hudson Valley in New York. Largely as a result, the U.S. semiconductor workforce today is highly international, especially at the higher-skilled end of the distribution.

Strengthening the U.S. semiconductor workforce starts with increasing the supply of American citizens who have the requisite training to take highskilled and high-paying jobs in the semiconductor industry. This report argues that workforce needs will evolve and shift-what is needed, then, is broad investments in education in semiconductor-relevant fields, starting in grade school and continuing through graduate school and workforce development programs.

But the supply of American-born talent alone will not be sufficient in the near term to meet companies' workforce needs. High-skilled immigration reform is one of the best levers available to policymakers seeking to preserve U.S. leadership in the semiconductor industry. The risk, of course, is that foreign workers will come to the United States for a short time, acquire valuable skills and industry secrets, and take them back to their home countries. Immigration reform must therefore be accompanied by measures to mitigate the risks of technology transfer. These two policy priorities are not mutually exclusive.

The United States leads the world in many parts of the semiconductor supply chain. Continued leadership is not assured, but if the country can leverage its workforce strengths-a deep bench of domestic and international scientists and engineers, and the world-class universities that attract and train themthen there is more than enough reason for optimism. 


\section{Acknowledgments}

The authors gratefully acknowledge Melissa Flagg, Douglas Fuller, James Lewis, Igor Mikolic-Torreira, Dewey Murdick, Falan Yinug, and especially James Dunham and Saif Khan for valuable feedback and assistance, and Dale Brauner, Matt Mahoney, Lynne Weil, Alexandra Vreeman, and Danny Hague for editorial support. Any remaining errors are our own. The use of NSF data does not imply NSF endorsement of the research, research methods, or conclusions contained in this report.

(C) $(1) \Theta$

(C) 2020 by the Center for Security and Emerging Technology. This work is licensed under a Creative Commons Attribution-Non Commercial 4.0 International License.

To view a copy of this license, visit:

https://creativecommons.org/licenses/by-nc/4.0/.

Document Identifier: doi: 10.51593/20190035 


\section{Appendix A: Definitional and Measurement Issues}

Box 3 outlined the different datasets we used in studying the U.S. semiconductor workforce; each of those datasets has limitations that make it difficult to adhere to a consistent definition of semiconductor talent. To lay the groundwork for future analysis and to enable readers to interpret our findings with the appropriate caution, this section briefly summarizes these limitations and our choices. In general, researchers face trade-offs between being overly inclusive-using categories that capture most workers and fields relevant to semiconductors but that may also include data irrelevant to the industry-and focusing on a narrow slice of the sector at the risk of excluding relevant information. When necessary, this report erred on the side of being overly inclusive.

Semiconductor technology is highly complex and constantly changes, meaning it is difficult to define what occupations and skills are relevant to the semiconductor industry. For example, Bureau of Labor Statistics tabulations exclude about 56,400 people employed by "fabless" semiconductor firms, which are a relatively recent addition to the semiconductor supply chain. The Semiconductor Industry Association estimates that these workers make up almost a quarter of the total workforce. ${ }^{84}$ On the other hand, educational and patent statistics on fields relevant to the semiconductor industry-electrical engineering, computer science, and so forth-will include many inventions and people whose work is not related to semiconductors. Definitional issues are compounded by availability issues. The American Community Survey's data on workers in the semiconductor industry, for example, does not provide information about workers' educational background or specific employer (see Appendix B).

Finally, for reasons discussed in the first section of Chapter 3, our report focuses on the "high-skilled technical" part of the semiconductor workforce. Classifying jobs in this manner requires hand-coding based on occupational categories and job titles, which are available only in certain datasets. We discuss definitional and measurement choices associated with this concept in Appendices B and C. 


\section{Appendix B: American Community Survey Data}

Figure 1 shows the breakdown of the U.S. semiconductor workforce by worker nationality. The chart uses data from the American Community Survey, the largest household survey administered by the U.S. Census Bureau. This paper uses ACS data because-unlike U.S. green card data-it includes American as well as non-American workers located in the United States (see Appendix (), and-unlike other datasets maintained by the Bureau of Labor Statistics (BLS)-they track workers' citizenship and place of birth. ${ }^{85}$ However, ACS also has issues, mainly in its industry classification.

ACS reports workers' industry of employment using the North American Industry Classification System. Unfortunately, ACS data at the 6-digit NAICS code level is not publicly available. The publicly available but less granular four-digit NAICS coding for the semiconductor industry includes employees of both semiconductor firms and "other electronic component and products" firms, yielding a total of approximately 700,000 workers. Many of these 700,000 workers do not belong to the semiconductor industry, but instead work on other electronic components. According to estimates from the Semiconductor Industry Association based on a combination of internal SIA surveys and county-level BLS data, the semiconductor workforce comprises closer to 240,000 workers. ACS data also exclude fabless semiconductor design firms, who employ about 56,400 workers according to SIA estimates.

The focus of this paper is on the high-skilled and technical semiconductor workforce, and thus Figure 2 presents data only on this subset of employees working in the "electronic components and products" industry. The ACS does not define occupations as "high-skilled" or "technical," so limiting the data to the population of interest required us to hand-code occupations for relevance. Ultimately, only a third of workers in semiconductor-related industries fall into the "high-skilled technical" category as operationalized in this paper. To illustrate our coding choices, the two tables below present examples of occupations included and excluded from the category "highskilled technical," out of a list of all 279 occupations within the "electronic components and products" industry (NAICS code 334M2).

Table 5 shows occupations coded as "high-skilled technical." The term "technical" means that these workers were directly involved in the creation of semiconductor products: most are engineers, technicians, computer systems analysts, or their direct managers. "High-skilled" means that these occupations require significant training-at least a bachelor's (and often a 
graduate) degree in a STEM discipline, as well as on-the-job training-and typically earn higher wages than other workers.

Table 5. Top 10 semiconductor industry occupations counted as "high-skilled technical" for ACS analysis in this paper, by number of workers.

\begin{tabular}{|l|r|}
\hline Occupation & \multicolumn{1}{|l|}{ Count } \\
\hline 1530: Miscellaneous Engineers, Including Nuclear Engineers & 49,463 \\
\hline 1410: Electrical and Electronics Engineers & 39,833 \\
\hline 1550: Engineering Technicians, Except Drafters & 36,280 \\
\hline 1020: Software Developers, Applications and Systems Software & 35,603 \\
\hline 300: Architectural And Engineering Managers & 10,513 \\
\hline 1430: Industrial Engineers, Including Health and Safety & 8,675 \\
\hline 1010: Computer Programmers & 6,834 \\
\hline 140: Industrial Production Managers & 6,659 \\
\hline 1450: Materials Engineers & 6,647 \\
\hline 110: Computer And Information Systems Managers & 6,397 \\
\hline Other & 14,565 \\
\hline Total & 221,469 \\
\hline
\end{tabular}

Source: CSET analysis of 2012-2016 ACS data.

Table 6 shows the top 10 most common occupations not classified as "highskilled-technical." Occupations we categorized as "non-technical" are those such as "Sales Representatives" and "Lawyers," which involve tasks not directly involved in the creation of semiconductors and related products. Occupations we categorized as "non-high-skilled" are those such as "Inspectors, Testers, Sorters, Samplers, and Weighers," which are generally dominated by workers with less than a bachelor's degree and pay lower hourly wages. 
Table 6. Top 10 semiconductor industry occupations not counted as "highskilled technical" for ACS analysis in this paper, by number of workers.

\begin{tabular}{|l|r|}
\hline Occupation & Count \\
\hline 7720: Electrical, Electronics, and Electromechanical Assemblers & 56,703 \\
\hline $\begin{array}{l}\text { 430: Miscellaneous Managers, Including Funeral Service Managers and } \\
\text { Postmasters And Mail Superintendents }\end{array}$ & 43,476 \\
\hline 8740: Inspectors, Testers, Sorters, Samplers, and Weighers & 28,287 \\
\hline 4850: Sales Representatives, Wholesale and Manufacturing & 24,465 \\
\hline 8220: Miscellaneous Metal Workers and Plastic Workers, Including Multiple & 21,368 \\
\hline Machine Tool Setters & 20,894 \\
\hline 7700: First-Line Supervisors of Production and Operating Workers & 15,407 \\
\hline 7750: Miscellaneous Assemblers and Fabricators & 14,280 \\
\hline 8965: Miscellaneous Production Workers, Including Semiconductor Processors & 14,261 \\
\hline 50: Marketing and Sales Managers & 10,272 \\
\hline 800: Accountants and Auditors & 224,086 \\
\hline Other & 43,499 \\
\hline Total & \\
\hline
\end{tabular}

Source: CSET analysis of 2012-2016 ACS data. 


\section{Appendix C: Green Card Data}

Several U.S. departments charged with administering and enforcing immigration regulations regularly release data on the number and characteristics of immigrants. The most detailed of these is the Department of Labor's "PERM" data, which includes information on foreign workers for whom employers initiated a labor certification process since $2010 .{ }^{86}$ This process is a prerequisite for green card sponsorship. Data on these workers includes their place of origin, their educational and professional backgrounds, and characteristics of their prospective jobs, including the name of their prospective employer.

The PERM dataset links individual workers to the companies that sponsor them, and thereby to specific parts of the semiconductor supply chain. The supply chain analysis that produced Figures 6 and 7 in the paper started by identifying one to three major U.S. employers in each of four parts of the supply chain. Approximately 787,000 individuals are included in the original 2010-2018 data: out of these individuals, 10,782 were sponsored by one of the 10 semiconductor companies we identified. We then looked at workers' job titles and, in a process similar to that we used for ACS data (see Appendix B), hand-coded them as technical or non-technical. After filtering for technical workers, 9,543 green card applicants remained; this population is the basis for the supply chain analysis in Figures 6 and 7. Data on academic background was available for only 57 percent of green card applicants, or 5,425 individuals. It is possible that the fields of study we tend to observe in the data differ from those that are missing, influencing our analysis of feeder disciplines. Nationality data was available for all individuals in the sample. Below we report the data broken down by specific companies.

Table 7 presents workers' academic backgrounds disaggregated by company. In general, the breakdown across employers in a given part of the supply chain does not appear to vary dramatically. For example, while computer science was the second most common educational background in three out of four parts of the supply chain, mechanical engineering was much more common among workers seeking jobs at SME firms. This result is not driven by a single large, idiosyncratic firm: mechanical engineering was a particularly common background for employees seeking work at all three major SME firms in our sample. 
Table 8 below presents a firm-by-firm breakdown of the nationalities of workers in the PERM data (aggregates by supply chain segment were shown in Figure 7). India and China are the top two places of origin for PERM applicants at almost all firms. Taiwan and South Korea are also common points of origin, but Canada, Israel, France, and Russia also appear frequently. There are some interesting differences across parts of the supply chain. For example, Canadians are disproportionately represented among design firm staff; Canada is the third most common place of origin after India and China across all three design firms in our sample. 
Table 7. Field of highest degree for green card applicants by firm, 20102018.

\begin{tabular}{|c|c|c|c|c|c|c|c|}
\hline \multicolumn{8}{|c|}{ Fabrication Firms } \\
\hline & $\begin{array}{l}\text { Electrical, Electronic, } \\
\text { Computer Engineering }\end{array}$ & $\begin{array}{l}\text { Materials } \\
\text { Science and } \\
\text { Engineering }\end{array}$ & $\begin{array}{l}\text { Chemical } \\
\text { Engineering }\end{array}$ & Physics & $\begin{array}{l}\text { Mechanical } \\
\text { Engineering }\end{array}$ & $\begin{array}{l}\text { Computer } \\
\text { Science }\end{array}$ & Total \\
\hline GlobalFoundries & 124 & 33 & 26 & 20 & 16 & 5 & 268 \\
\hline \multicolumn{8}{|c|}{ Electronic Design Automation Firms } \\
\hline & $\begin{array}{l}\text { Electrical, Electronics, } \\
\text { Computer Engineering }\end{array}$ & $\begin{array}{l}\text { Computer } \\
\text { Science }\end{array}$ & Physics & $\begin{array}{l}\text { Mechanical } \\
\text { Engineering }\end{array}$ & $\begin{array}{l}\text { Materials } \\
\text { Science and } \\
\text { Engineering }\end{array}$ & $\begin{array}{l}\text { Chemical } \\
\text { Engineering }\end{array}$ & Total \\
\hline Synopsys & 316 & 51 & 1 & 3 & 1 & 1 & 407 \\
\hline Cadence & 258 & 23 & 7 & 2 & 1 & 0 & 298 \\
\hline Mentor Graphics & 58 & 11 & 1 & 3 & 1 & 0 & 81 \\
\hline Total & 632 & 85 & 8 & 8 & 3 & 1 & 786 \\
\hline \multicolumn{8}{|c|}{ Semiconductor Manufacturing Equipment Firms } \\
\hline & $\begin{array}{l}\text { Electrical, Electronics, } \\
\text { Computer Engineering }\end{array}$ & $\begin{array}{l}\text { Mechanical } \\
\text { Engineering }\end{array}$ & $\begin{array}{l}\text { Chemical } \\
\text { Engineering }\end{array}$ & $\begin{array}{l}\text { Materials } \\
\text { Sciences and } \\
\text { Engineering }\end{array}$ & Physics & $\begin{array}{l}\text { Computer } \\
\text { Science }\end{array}$ & Total \\
\hline Applied Materials & 81 & 59 & 36 & 32 & 9 & 7 & 283 \\
\hline LAM Research & 33 & 35 & 17 & 19 & 14 & 6 & 144 \\
\hline KLA-Tencor & 51 & 24 & 8 & 6 & 12 & 6 & 128 \\
\hline Total & 165 & 118 & 61 & 57 & 35 & 19 & 555 \\
\hline \multicolumn{8}{|c|}{ Design Firms } \\
\hline & $\begin{array}{l}\text { Electrical, Electronics, } \\
\text { Computer Engineering }\end{array}$ & $\begin{array}{l}\text { Computer } \\
\text { Science }\end{array}$ & $\begin{array}{l}\text { Mechanical } \\
\text { Engineering }\end{array}$ & Physics & $\begin{array}{l}\text { Chemical } \\
\text { Engineering }\end{array}$ & $\begin{array}{l}\text { Materials } \\
\text { Science and } \\
\text { Engineering }\end{array}$ & Total \\
\hline Qualcomm & 1964 & 355 & 17 & 11 & 5 & 2 & 2,354 \\
\hline Broadcom & 446 & 36 & 3 & 5 & 0 & 1 & 491 \\
\hline Nvidia & 443 & 126 & 13 & 4 & 3 & 0 & 589 \\
\hline Total & 2853 & 517 & 33 & 20 & 8 & 3 & 3,434 \\
\hline
\end{tabular}

Source: CSET analysis of Department of Labor PERM data, 2010-2018. Note: The "Total"

column also includes workers with other, less common educational backgrounds. 
Table 8. Place of origin for green card applicants by firm, 2010-2018.

\begin{tabular}{|c|c|c|c|c|c|c|c|c|}
\hline \multicolumn{9}{|c|}{ Fabrication Firms } \\
\hline & India & China & Korea & Singapore & Taiwan & Malaysia & Philippines & Total \\
\hline GlobalFoundries & 138 & 77 & 51 & 41 & 28 & 24 & 10 & 431 \\
\hline \multicolumn{9}{|c|}{ Electronic Design Automation Firms } \\
\hline & India & China & Taiwan & Korea & France & Canada & Armenia & Total \\
\hline \multirow[t]{2}{*}{ Synopsys } & 404 & 128 & 20 & 14 & 12 & 10 & 6 & 636 \\
\hline & India & China & Canada & Israel & Taiwan & Korea & Brazil & Total \\
\hline \multirow[t]{2}{*}{ Cadence } & 246 & 71 & 11 & 9 & 9 & 8 & 7 & 397 \\
\hline & India & Egypt & China & Russia & Mexico & Taiwan & France & Total \\
\hline Mentor Graphics & 87 & 23 & 13 & 6 & 4 & 4 & 3 & 162 \\
\hline \multicolumn{9}{|c|}{ Semiconductor Manufacturing Equipment Firms } \\
\hline & India & China & Korea & Taiwan & Israel & Japan & U.K. & Total \\
\hline \multirow[t]{2}{*}{ Applied Materials } & 153 & 66 & 39 & 30 & 21 & 20 & 9 & 387 \\
\hline & India & Korea & China & Taiwan & Japan & Canada & France & Total \\
\hline \multirow[t]{2}{*}{ LAM Research } & 67 & 38 & 26 & 15 & 10 & 7 & 4 & 191 \\
\hline & India & China & Korea & Canada & Taiwan & Israel & Singapore & Total \\
\hline KLA-Tencor & 96 & 58 & 13 & 10 & 9 & 8 & 7 & 231 \\
\hline \multicolumn{9}{|c|}{ Design Firms } \\
\hline & India & China & Canada & Korea & Taiwan & Iran & Pakistan & Total \\
\hline \multirow[t]{2}{*}{ Qualcomm } & 3,428 & 652 & 251 & 152 & 115 & 59 & 29 & 5,032 \\
\hline & India & China & Canada & Korea & Taiwan & France & Israel & Total \\
\hline \multirow[t]{2}{*}{ Broadcom } & 737 & 255 & 98 & 81 & 52 & 15 & 14 & 1,365 \\
\hline & India & China & Canada & Taiwan & Korea & Russia & France & Total \\
\hline Nvidia & 707 & 199 & 140 & 29 & 28 & 18 & 15 & 1,270 \\
\hline
\end{tabular}

Source: CSET analysis of Department of Labor PERM data, 2010-2018. Note: The "Total" column also includes workers with other, less common educational backgrounds. 


\section{Endnotes}

${ }^{1}$ In his account of the development of the MOS transistor, Chih-Tang Sah writes that "to those of us in the field, Kahng and Atalla are the recognized inventors of the modern MOSFET." But Sah notes that the Atalla-Kahng MOSFET built on tremendous contributions from many other engineers. Sah highlights in particular major contributions from nine other engineers who laid the groundwork for the Atalla-Kahng MOSFET. Four (Julius Lilienfeld, Robert Noyce, William Ross, and Jean Hoerni) were immigrants to the United States, four (Walter Brown, William Shockley, Walter Brattain, and John Bardeen) were American, and one (Walter Heil) worked in Europe, though he later immigrated to the United States. ChihTang Sah, "Evolution of the MOS Transistor-From Conception to VLSI," Proceedings of the IEEE76, no. 19 (October 1988).

2 For example, the Americans Shockley, Brattain, and Hoerni jointly received the 1956 Nobel Prize for their research into semiconductors and transistors, which played a key role in the subsequent development of the Atalla-Kahng MOSFET. See Sah, "Evolution of the MOS Transistor" and "The Nobel Prize in Physics 1956," NobelPrize.org, Nobel Media AB, 2020, https://www.nobelprize.org/prizes/physics/1956/summary.

3 Tekla S. Perry, "How the Father of FinFETs Helped Save Moore's Law," IEEE Spectrum, April 21, 2020, https://spectrum.ieee.org/semiconductors/devices/how-the-father-offinfets-helped-save-moores-law.

${ }^{4}$ David Schor, "TSMC Announces 6-Nanometer Process," WikiChip Fuse, April 16, 2019 , https://fuse.wikichip.org/news/2261/tsmc-announces-6-nanometer-process/.

${ }^{5}$ Schor, "TSMC Announces 6-Nanometer Process."

${ }^{6}$ Accomplished by TSMC's 7 nanometer chips. For date of volume production, see "TSMC Kicks Off Volume Production of 7nm Chips," AnandTech, April 24, 2018 , https://www.anandtech.com/show/12677/tsmc-kicks-off-volume-production-of-7nmchips. For their transistor density, see Scotten Jones, "TSMC and Samsung 5nm Comparison," SemiWiki.com, May 5, 2019, https://semiwiki.com/semiconductor-

manufacturers/samsung-foundry/8157-tsmc-and-samsung-5nm-comparison/.

${ }^{7}$ Moore's original paper predicted a doubling every year. He revised this to every two years in 1975. Gordon E. Moore, "Cramming more components onto integrated circuits,"

Electronics Magazine, 1965, 114-1 17. Gordon E. Moore, "Progress in Digital Integrated Electronics," IEDM Tech Digest, 1975, 11 -13.

8 "2020 SIA Factbook," Semiconductor Industry Association, 2020, https://www.semiconductors.org/wp-content/uploads/2020/04/2020-SIA-FactbookFINAL_reduced-size.pdf.

${ }^{9}$ Gartner predicts that semiconductor consumption by loT firms will increase from $\$ 29.6$ billion in 2018 to $\$ 63.9$ billion in 2023, a compound annual growth rate of 16.9 percent. Masatsune Yamaji, "Forecast, loT Semiconductors Worldwide, 2019 Update" (Gartner Research, September 3, 2019). 
https://www.gartner.com/en/documents/3956877/forecast-iot-semiconductorsworldwide-2019-update.

${ }^{10}$ Lawrence K. Harada, "Semiconductor Technology and U.S. National Security," Army War College, 2010, https://apps.dtic.mil/dtic/tr/fulltext/u2/a526581.pdf.

${ }^{11}$ Office of the Deputy Assistant Secretary of Defense for Industrial Policy, "Assessing and Strengthening the Manufacturing and Defense Industrial Base and Supply Chain Resiliency," 2018, https://media.defense.gov/2018/Oct/05/2002048904/-1/$1 / 1 /$ ASSESSING-AND-STRENGTHENING-THE-MANUFACTURING-AND\%20DEFENSEINDUSTRIAL-BASE-AND-SUPPLY-CHAIN-RESILIENCY.PDF, 89-91.

12 For example, Taiwan's TSMC has a majority of the world's logic foundry market share and is especially dominant at the latest nodes; Japan dominates in wafer manufacturing, handling, and marking; and the Dutch firm ASML has a majority of the global lithography market share and a monopoly on the latest generation (EUV photolithography) of lithography equipment. See Saif M. Khan, Alexander Mann, and Dahlia Peterson, "The Semiconductor Supply Chain: Assessing National Competitiveness," Center for Security and Emerging Technology (forthcoming).

${ }^{13}$ James A. Lewis, "Learning the Superior Techniques of the Barbarians: China's Pursuit of Semiconductor Independence" (Center for Strategic and International Studies, January 2019), https://csis-prod.s3.amazonaws.com/s3fspublic/publication/190115 Lewis Semiconductor v6.pdf.

${ }^{14}$ Andy Wong, "Trump administration weighs suspending program for foreign students, prompting backlash from business, tech," NBC News, May 15, 2020,

https://www.nbcnews.com/politics/immigration/trump-administration-weighs-suspendingprogram-foreign-students-prompting-backlash-business-n 1207251.

${ }^{15}$ Rachel Courtland, "Gordon Moore: The man whose name means progress," IEEE Spectrum, 2015, https://spectrum.ieee.org/computing/hardware/gordon-moore-theman-whose-name-means-progress, 112.

${ }^{16}$ The three firms that have managed to sustain Moore's Law are Intel, South Korea's Samsung, and Taiwan's TSMC. One of the key drivers of Moore's Law has been shrinking transistor sizes. But engineers seeking to build transistors at the latest (5 nanometer) chip node have to contend with quantum tunneling: barriers between the electrodes of a transistor are becoming so small that electrons can jump across them. Note that node names no longer correlate perfectly with transistor density: for example, many analysts believe Intel's "10nm node" is equivalent in capabilities to TSMC's "7nm node." Godfrey Cheng, "Moore's Law is not Dead," TSMC Blog, August 14, 2019,

https://www.tsmc.com/english/newsEvents/blog_article_20190814.htm. 
17 Studies show that the semiconductor workforce employs approximately 18 times more researchers today than it did in the 1970s, meaning that research productivity in the semiconductor industry is approximately 18 times lower than it was 50 years ago. They argue that this is in fact an exceptionally small decline in research productivity relative to other parts of the economy. This helps to explain why the semiconductor industry has such a voracious appetite for human capital: adding more researchers to the industry generates economic gains much faster than it does in other parts of the economy. See Nicholas Bloom, Charles I. Jones, John Van Reenen, and Michael Webb, "Are Ideas Getting Harder to Find?" American Economic Review 1 10, no. 4 (April 2020): 1104-1144.

${ }^{18}$ On difficulties estimating talent shortages, see Michael S. Teitelbaum, Falling Behind? Boom, Bust, \& the Global Race for Scientific Talent (Princeton, NJ: Princeton University Press), chapter 5 .

19 "SIA Workforce Roundtable Summary Report," Semiconductor Industry Association, March 16, 2018, https://www.semiconductors.org/wpcontent/uploads/2018/06/Roundtable Summary Report - FINAL.pdf.

${ }^{20}$ Chris Richard, Karthik Ramachandran, and Ivan Pandoy, "Looming Talent Gap Challenges Semiconductor Industry," SEMI, 2018, https://www.semi.org/en/node/581.

${ }^{21}$ See, for example, Defense Science Board Taskforce on Export of U.S. Technology, "An Analysis of Export Control of U.S. Technology: A DOD Perspective" (Washington, D.C: Office of the Director of Defense Research and Engineering, February 4, 1976), https://apps.dtic.mil/dtic/tr/fulltext/u2/a022029.pdf.

22 Indeed, even within-firm knowledge transfers are exceptionally challenging and have forced semiconductor manufacturers to develop elaborate management procedures to ensure that production processes can be replicated at new sites: Intel's "Copy Exactly!" model is the canonical example. For more on the importance of tacit know-how and the challenges of developing the "dynamic capacity" for consistent innovation in the semiconductor industry, see Jeffrey T. Macher, and David C. Mowery, "Measuring dynamic capabilities: practices and performance in semiconductor manufacturing," British Journal of Management 20, no. s1 (February 2009): S41-S62.

${ }^{23}$ Gerald Carlino and William R. Kerr, "Agglomeration and Innovation" in Handbook of Regional and Urban Economics (Amsterdam: North Holland, 2015): 20-36. On talent hubs and productivity, see also Enrico Moretti, "The effect of high-tech clusters on the productivity of top inventors," NBER Working Paper Series no. w26270 (2019), https://www.nber.org/papers/w26270\#fromrss.

${ }^{24}$ For example, 10 years ago, there were 130 publicly traded semiconductor firms globally-today there are 72. Industry observers expect this trend to continue and even intensify, perhaps cutting the number of public semiconductor firms by 50 percent over the next three to five years. "Semiconductor Valuations Support Further Industry Consolidation." Seeking A/pha, June 7, 2019 , https://seekingalpha.com/article/4269132-semiconductorvaluations-support-industry-consolidation. 
25 "Comments to the National Institute of Standards and Technology on 'Current and Future Workforce Needs to Support a Strong Domestic Semiconductor Industry. "' Semiconductor Industry Association, August 15, 2019, https://www.semiconductors.org/wpcontent/uploads/2018/11/NIST-workforce-RFI-august-2018.pdf, 7. Of course, access to talent is not the only factor firms consider when choosing where to locate. In one survey, managers of semiconductor firms rated access to talent as the second most important factor after tax advantages, tied with quality of water supply and proximity to existing utilities; see Robert C. Leachman, and Chien H. Leachman, "Globalization of semiconductors: Do real men have fabs, or virtual fabs?" in Locating Global Advantage: Industry Dynamics in the International Economy (Palo Alto: Stanford University Press, 2003): 256.

${ }^{26}$ AnnaLee Saxenian, "Silicon Valley's New Immigrant High-Growth Entrepreneurs," Economic Development Quarterly 16 no. 1 (2002), 20-31.

${ }^{27}$ AnnaLee Saxenian and Jinn-Yuh Hsu, "The Silicon Valley-Hsinchu connection: technical communities and industrial upgrading," Industrial and Corporate Change 10, no. 4 (2001): 893-920.

28 Stephen Nellis and David Shepardson, "Taiwan's TSMC to build Arizona chip plan as U.S.-China tech rivalry escalates," Reuters, May 14, 2020,

https://www.reuters.com/article/us-usa-semiconductors-tsmc/taiwan-semiconductor-toannounce-plans-for-us-factory-source-idUSKBN22Q38T.

${ }^{29}$ Jaeyong Song, "Technological Catching-up of Korea and Taiwan in the Global Semiconductor Industry: A Study of Modes of Technology Sourcing," APEC Study Center Discussion Paper Series no. 15 (December 2000).

${ }^{30}$ BLS projects some lower-skilled occupations to see especially dramatic job losses. For example, 14,200 "inspectors, testers, sorters, samplers, and weighers" worked in semiconductor manufacturing and related industries in 2018 , but BLS predicts 4,000 (27.9 percent) of these jobs will disappear by 2028 . See "334400 Semiconductor and other electronic component manufacturing: Employment by industry, occupation, and percent distribution, 2018 and projected 2028," Employment Projections, Bureau of Labor Statistics, https://data.bls.gov/projections/nationalMatrix? queryParams=334400\&ioType=i. Note that BLS projections are based on the broad "semiconductor and other component manufacturing" industry. Job losses may be less severe for semiconductor workers, and more severe in the "other component manufacturing" parts of the industry.

${ }^{31}$ BLS projects that employment for Electrical and Electronics Engineers and Software Applications Developers will stay roughly flat, while employment will decrease in the remaining fourteen occupations we coded as "high-skilled technical" (see Appendix B). 
${ }^{32}$ Asa Fitch, Kate O'Keeffe and Bob Davis, "Trump and Chip Makers Including Intel Seek Semiconductor Self-Sufficiency," Wall Street Journal, May 1 1, 2020,

https://www.wsi.com/articles/trump-and-chip-makers-including-intel-seek-semiconductorself-sufficiency-1 1589103002; Bob Davis, Asa Fitch and Kate O'Keeffe, "Semiconductor Industry to Lobby for Billions to Boost U.S. Manufacturing," Wall Street Journal, May 31 , 2020, https://www.wsi.com/articles/semiconductor-industry-to-lobby-for-billions-toboost-u-s-manufacturing-11590919201; Asa Fitch and Kate O'Keeffe, "Lawmakers Propose Spending Billions to Strengthen U.S. Chip Industry." Wall Street Journal, June 10, 2020, https://www.wsi.com/articles/lawmakers-propose-spending-billions-to-strengthenu-s-chip-industry-11591825784.

${ }^{33}$ Falan Yinug, "U.S. Semiconductor Industry Employment" (Semiconductor Industry Association, January 2015), https://www.semiconductors.org/wpcontent/uploads/2018/06/Jobs-Issue-Paper January 2015-formatted.pdf.

${ }^{34}$ For more details on NSF's Survey of Earned Doctorates and further analysis of stay rates, see Remco Zwetsloot, Jacob Feldgoise and James Dunham, Trends in U.S. Intention-to-Stay Rates of International P.D. Graduates Across Nationality and STEM Fields (Center for Security and Emerging Technology: April 2020), https://cset.georgetown.edu/wpcontent/uploads/CSET-Trends-in-U.S.-Intention-to-Stay-Rates.pdf.

35 "Patent Pending: How Immigrants Are Reinvesting the American Economy" (The Partnership for a New American Economy, June 2012), http://www.newamericaneconomy.org/sites/all/themes/pnae/patent-pending.pdf.

${ }^{36}$ Ernest Miguelez and Carsten Fink, Measuring the international mobility of inventors: A new database, WIPO Vol. 8, 2013, https://www.wipo.int/publications/en/details.jsp?id=3952\&plang=EN.

37 "Testimony of Patrick J. Duffy, Human Resources Attorney for Intel Corporation," Senate Judiciary Committee, September 16, 2003.

${ }^{38}$ The data only indicate the institution at which each worker gained their highest educational credential. If anything this is likely an underestimate, as some workers may have attended U.S. universities at an earlier stage of their education, then gone to another country for their highest level of education, only to return to the United States for work.

${ }^{39}$ U.S. Citizenship and Immigration Services, "F-1 Students Obtaining Another Nonimmigrant Classification" (Washington, D.C.: Department of Homeland Security, July 2019), https://www.uscis.gov/sites/default/files/document/presentations/Report - F1 Students Obtaining Another Nonimmigrant Classification.pdf.

40 "Global Ranking of Academic Subjects, 2019," Academic Ranking of World Universities, http://www.shanghairanking.com/Shanghairanking-Subject-Rankings/index.html.

${ }^{41}$ Michael G. Finn and Leigh Ann Pennington, "Stay Rates of Foreign Doctorate Recipients from U.S. Universities, 2013" (Oak Ridge Institute for Science and Education, January, 2018), https://orise.orau.gov/stem/reports/stay-rates-foreign-doctorate-recipients2013.pdf. 
${ }^{42}$ In recent years, efficiency and speed boosts have increasingly derived from specialized chip designs. For example, some specialized Al chips can give speed and efficiency boosts of 100X or even 1000X-equivalent to 26 years of CPU improvements. Defense Advanced Research Projects Agency, A DARPA Approach to Trusted Microelectronics (Arlington, VA: Department of Defense), 2, https://www.darpa.mil/attachments/Background FINAL3.pdf. See also Saif M. Khan and Alexander Mann, "Al Chips: What They Are and Why They Matter" (Center for Security and Emerging Technology, April 2020), https://cset.georgetown.edu/research/ai-chips-what-they-are-and-why-they-matter/.

${ }^{43}$ See for example, James Morra, "China's Tsinghua Unigroup Invests $\$ 30$ Billion in Memory Chip Fab," Electronic Design, January 25, 2015, https://www.electronicdesign.com/technologies/memory/article/21802194/chinastsinghua-unigroup-invests-30-billion-in-memory-chip-fab.

${ }^{44}$ ASML sold 7 EUV scanners in the second quarter of 2020 for a total of more than one billion dollars, implying an average per-unit cost of more than $\$ 100$ million. ASML, "ASML 2020 Second-Quarter" (Slide 10), July 15, 20020, https://www.asml.com/en/investors/financial-results/q2-2020.

${ }^{45}$ James A. Lewis, "Learning the Superior Techniques of the Barbarians" (Center for Strategic \& International Studies, January 2019), https://www.csis.org/analysis/chinas-pursuitsemiconductor-independence.

46 “美国统治力惊人, 中国半导体如何在炮火中匍匐前进?” ("The Dominance of the United States is Staggering. How can Chinese Semiconductors Advance?"), EE Focus, November 21, 2018, https://www.eefocus.com/mcu-dsp/424622/rO.

${ }^{47}$ Permanent Subcommittee on Investigations, Threats to the US Research Enterprise, Senate Committee on Homeland Security and Governmental Affairs, November 2019, https://www.hsgac.senate.gov/imo/media/doc/2019-1118\%20PSI\%20Staff\%20Report\%20-\%20China's\%20Talent\%20Recruitment\%20Plans.pdf, 38.

${ }^{48}$ Office of the United States Trade Representative, Findings of the Investigation into China's Acts, Policies, and Practices Related to Technology Transfer, Intellectual Property, and Innovation Under Section 301 of the Trade Act of 1974, 2018, https://ustr.gov/sites/default/files/Section\%20301\%20FINAL.PDF, 182.

${ }^{49}$ Remco Zwetsloot, "China's Approach to Tech Talent Competition: Policies, Results, and the Developing Global Response" (Brookings, April 2020), https://cset.georgetown.edu/wpcontent/uploads/Zwetsloot\%E2\%80\%94Chinas-Approach-to-Tech-Talent.pdf.

${ }^{50}$ Unfortunately, similarly detailed data are not available for graduates at other degree levels (bachelor's, master's, or post-doctoral researchers) or for scientists and engineers working in the private sector.

${ }^{51}$ Lewis, "Learning the Superior Techniques of the Barbarians." 
${ }^{52}$ See Lu Miao and Huiyao Wang, International Migration of China: Status, Policy and Social Responses to the Globalization of Migration (Singapore: Springer Nature, 2017): 11. On retention, they note that "attracting overseas Chinese talent back is just the first step. The crucial issue is devising ways of ensuring that they stay in China. Many returnees find adapting to life back in their motherland to be much harder than they had imagined" (58). The authors run the Center for China and Globalization, a prominent think tank, and Wang is a State Counselor.

${ }^{53}$ Britta Glennon, "How Do Restrictions on High-Skilled Immigration Affect Offshoring? Evidence from the H-1B Program," February 2020, https://papers.ssrn.com/sol3/papers.cfm?abstract id=3547655; Margaret E. Peters, Trading Barriers: Immigration and the Remaking of Globalization (Princeton, NJ: Princeton University Press, 2017).

${ }^{54}$ For example, reports indicate that semiconductor companies favor U.S. hires for "IP and trade secrets protection" reasons, with some firms "holding back key processes from Chinese employees and allowing access only to low-end technologies." See, respectively, Semiconductor Industry Association, "Roundtable Summary Workforce Report," 6, and Lewis, "Learning the Superior Techniques," 8.

${ }^{55}$ For an overview of these tools, see Permanent Subcommittee on Investigations, "Threats to the US Research Enterprise."

${ }^{56}$ James A. Lewis, "Emerging Technologies and Managing the Risk of Technology Transfer to China" (Center for Strategic \& International Studies, September 2019),

https://www.csis.org/analysis/emerging-technologies-and-managing-risk-tech-transferchina.

${ }^{57}$ Kensaku lhara, "Taiwan Loses 3000 Chip Engineers to 'Made in China 2025,'" Nikkei Asian Review, December 3, 2019, https://asia.nikkei.com/Business/China-tech/Taiwanloses-3-000-chip-engineers-to-Made-in-China-2025; see also Yimou Li, "China lures chip talent from Taiwan with fat salaries, perks," Reuters, September 3, 2018, https://www.reuters.com/article/us-china-semiconductors-taiwan-insight/china-lures-chiptalent-from-taiwan-with-fat-salaries-perks-idUSKCN1 LKOH1. For criticism, see Douglas Fuller, "tens of thousands is a nonsense claim," Twitter, June 26, 2020, https://twitter.com/FuDaoge/status/1276519499177459712? s=20, and Douglas Fuller email correspondence with the authors.

${ }^{58}$ Dr. Christopher Ashley Ford, "Bureaucracy and Counterstrategy: Meeting the China Challenge," Remarks at the Conference on Great Power Competition, September 1 1, 2019, Ft. Belvoir, VA, https://www.state.gov/bureaucracy-and-counterstrategy-meeting-thechina-challenge/.

${ }^{59}$ Zwetsloot, "China's Approach to Tech Talent Competition."

${ }^{60}$ Daniel Kliman, Ben FitzGerald, Kristine Lee, and Joshua Fitt, "Forging an Alliance Innovation Base" (Center for a New American Security, March 2020), https://www.cnas.org/publications/reports/forging-an-alliance-innovation-base; Andrew Imbrie and Ryan Fedasiuk, "Untangling the Web: Why the U.S. Needs Allies to Defend 
Against Technology Transfer" (Brookings, April 2020), https://cset.georgetown.edu/wpcontent/uploads/Imbrie-Fedasiuk\%E2\%80\%94Untangling-the-Web.pdf.

${ }^{61}$ Semiconductor Industry Association, "Comments to the National Institute of Standards and Technology," 9.

62 "Academic Ranking of World Universities in Engineering/Technology and Computer Sciences," comparing rankings for 2007 and 2016;

http://www.shanghairanking.com/FieldENG2016.html.

${ }^{63}$ Janet Lorin, "U.S. Colleges Brace for a Devastating Summer and Fall," Bloomberg, April 19, 2020, https://www.bloomberg.com/news/articles/2020-04-19/u-s-colleges-bracefor-covid-19-to-hurt-summer-and-fall-finances.

${ }^{64}$ For a broader discussion of why graduate education in the United States has internationalized to such a great extent, see Alan Leshner and Layne Scherer, "Graduate STEM Education for the 21 st Century" (Washington, D.C.: The National Academies Press, 2018), https://www.nationalacademies.org/our-work/reshaping-graduate-stemeducation-for-the- 21 st-century.

${ }^{65}$ In one example of cross-disciplinary work advancing semiconductor innovation, researchers in Al have begun to apply machine learning techniques to chip design; see, e.g., Anna Goldie and Azalia Mirhoseini, "Chip Design with Deep Reinforcement Learning," Google A/ Blog, April 23, 2020, https://ai.googleblog.com/2020/04/chip-design-withdeep-reinforcement.html.

${ }^{66}$ John F. Sargent, Jr., "Revisiting the Doubling Effort: Trends in Federal Funding for Basic Research in the Physical Sciences and Engineering" (Congressional Research Service, November 2018), https://fas.org/sgp/crs/misc/IN1 1001.pdf. In FY2015, the federal government spent more than $\$ 30$ billion on $R \& D$ in the life sciences, compared to $\$ 12$ billion in engineering, $\$ 6.5$ billion in the physical sciences, and close to $\$ 4$ billion in the computer sciences and mathematics; see "Recent Trends in U.S. Federal Support for R\&D," Science and Engineering Indicators 2018, National Science Board, https://www.nsf.gov/statistics/2018/nsb20181/report/sections/research-anddevelopment-u-s-trends-and-international-comparisons/recent-trends-in-federal-support-foru-s-r-d.

${ }^{67}$ Charles W. Wessner, "The New York Nanotechnology Initiative" in Best Practices in State and Regional Innovation Initiatives: Competing in the 21 st Century (Washington, D.C.: National Academies Press, 2013), https://www.ncbi.nlm.nih.gov/books/NBK158826/.

${ }^{68}$ Wessner, "The New York Nanotechnology Initiative."

69 "DARPA Electronics Resurgence Initiative," DARPA, April 2, 2020, https://www.darpa.mil/work-with-us/electronics-resurgence-initiative.

${ }^{70}$ See, e.g., Virginia Tech Career and Professional Development, "Internships and Co-ops," https://career.vt.edu/experience/ceip/ceip-internship-coop.html. 
71 "Education and Training Programs," TSRI.org, https://www.tsri.org.tw/en/training.html.

72 See, e.g., Richard B. Freeman and John Van Reenan, "Be Careful What You Wish For," Issues in Science and Technology 21, no. 8 (Fall 2008), https://issues.org/p freeman/ and Paula Stephan, How Economics Shapes Science (Cambridge, MA: Harvard University Press, 2015).

${ }^{73}$ One informal assessment by the industry concludes: "We continue to anticipate increased need for workers with advanced degrees in hardware engineering, software engineering, computer engineering, electrical engineering, material science, physics, and chemistry. Artificial intelligence/machine learning, autonomous driving, data science, computer vision, and networking are important emerging areas." See Semiconductor Industry Association, "Comments to the National Institute of Standards," 8.

${ }^{74}$ Semiconductor Industry Association, "Workforce Roundtable Summary Report," 6.

${ }^{75}$ Zachary Arnold and Remco Zwetsloot, "Foreign Brains Help America Compete," Wall Street Journal, January 29, 2020, https://www.wsi.com/articles/foreign-brains-helpamerica-compete-1 1580341875; Andy Wong, "Trump administration weighs suspending program for foreign students, prompting backlash from business, tech."

76 Patrick Duffy, "Declaration of Patrick Duffy," Washington Alliance of Technology Workers v. United States Department of Homeland Security, et al., Civil Action No.: 1:16-cv-1 170 RBW, October, 18, 2018, https://www.courtlistener.com/recap/gov.uscourts.dcd.179734/gov.uscourts.ded. 17973 4.37.3.pdf.

77 David J. Bier, "Backlog for Skilled Immigration Tops 1 Million: Over 200,000 Indians Could Die of Old Age While Awaiting Green Cards" (Cato Institute, March 2020), Table 2, https://www.cato.org/publications/immigration-research-policy-brief/backlog-skilledimmigrants-tops-1-million-over. The 89-year estimate assumes all Indian green card applicants in the process today would have to be granted a green card before the current applicant could be processed. The 39-year estimate accounts for the fact that a large number of applicants who are in the process today would either voluntarily drop out or pass away before receiving a green card. For Chinese citizens, the equivalent estimates are nine to 11 years.

${ }^{78}$ For more detailed recommendations and background on immigration policy, see Zachary Arnold, Roxanne Heston, Remco Zwetsloot, and Tina Huang, Immigration Policy and the U.S. A/ Sector (Center for Security and Emerging Technology, September 2019), https://cset.georgetown.edu/research/immigration-policy-and-the-u-s-ai-sector/; and Remco Zwetsloot, James Dunham, Zachary Arnold, and Tina Huang, Keeping Top A/ Talent in the United States (Center for Security and Emerging Technology, December 2019), https://cset.georgetown.edu/research/keeping-top-ai-talent-in-the-united-states/. 
79 The H-1B cap was set at 65,000 per year in 1990 , and temporarily increased to 195,000 between the late 1990s and early 2000 s before reverting back to the original cap in 2004. Since 2007, the cap has remained unchanged at 85,000 (non-profit employers exempted). For background on the temporary and permanent employment-based immigration programs in the United States, see, respectively, Jill H. Wilson, "Temporary Professional, Managerial, and Skilled Foreign Workers: Policy and Trends" (Congressional Research Service, August 2016), https://www.everycrsreport.com/files/20160809 R43735 29d6335d2f0c42085aeda 53034632d 16a2647ea6.pdf and Kandel, "The Employment-Based Immigration Backlog."

${ }^{80}$ Daniel Costa and Ron Hira, "H 1-B Visas and Prevailing Wage Levels," Economic Policy Institute, May 4, 2020, https://www.epi.org/publication/h-1b-visas-and-prevailing-wagelevels/; for a different perspective, see David J. Bier, "100\% of H-1B Employers Offer Average Market Wages-78\% Offer More," CATO Institute, May 18, 2020, https://www.cato.org/blog/100-h-1 b-employers-offer-average-market-wages-78-offermore.

${ }^{81}$ Yinug, "U.S. Semiconductor Industry Employment."

${ }^{82}$ NAICS codes are maintained by the Economic Classification Policy Committee (ECPC) within the Office of Management and Budget, assisted by staff from the Bureau of Economic Analysis, the Bureau of Labor Statistics, and the Census Bureau. The codes are maintained in collaboration with Statistics Canada and Mexico's Instituto Nacional de Estadística y Geografía.

${ }^{83}$ Office of Management and Budget, "Notice of Solicitation for Proposals to Revise Portions of NAICS for 2012," Federal Register, January 7, 2009, 764,

https://www.govinfo.gov/content/pkg/FR-2009-01-07/pdf/FR-2009-01-07.pdf.

${ }^{84}$ Yinug, "U.S. Semiconductor Industry Employment."

${ }^{85}$ The BLS collects individual-level data via its monthly Current Population Survey, but this survey codes only whether individuals are "foreign-born" or "native-born" - nationality data is not available; see "Labor Force Statistics from the Current Population Survey," U.S. Bureau of Labor Statistics, https://www.bls.gov/cps/.

${ }^{86}$ Employment and Training Administration, "OFLC Performance Data," United States Department of Labor, April 15, 2020, https://www.foreignlaborcert.doleta.gov/performancedata.cfm. 